\title{
Terminus advance, kinematics and mass redistribution during eight surges of Donjek Glacier, St. Elias Range, Canada, 1935 to 2016
}

\author{
WILLIAM KOCHTITZKY, ${ }^{1,2}$ @ 1 HESTER JISKOOT, ${ }^{3}$ (1) LUKE COPLAND, ${ }^{4}$ \\ ELLYN ENDERLIN,${ }^{1,2,5}$ ROBERT MCNABB ${ }^{6}{ }^{\text {KARL KREUTZ, }}{ }^{1,2}$ BRITTANY MAIN ${ }^{4}$ \\ ${ }^{1}$ School of Earth and Climate Sciences, University of Maine, Orono, Maine, USA \\ ${ }^{2}$ Climate Change Institute, University of Maine, Orono, Maine, USA \\ ${ }^{3}$ Department of Geography, University of Lethbridge, Lethbridge, AB, Canada \\ ${ }^{4}$ Department of Geography, Environment and Geomatics, University of Ottawa, Ottawa, ON, Canada \\ ${ }^{5}$ Department of Geosciences, Boise State University, Boise, ID, USA \\ ${ }^{6}$ Department of Geosciences, University of Oslo, Oslo, Norway \\ Correspondence: William Kochtitzky <William.kochtitzky@maine.edu>
}

\begin{abstract}
Donjek Glacier has an unusually short and regular surge cycle, with eight surges identified since 1935 from aerial photographs and satellite imagery with a $\sim 12$ year repeat interval and $\sim 2$ year active phase. Recent surges occurred during a period of long-term negative mass balance and cumulative terminus retreat of $2.5 \mathrm{~km}$ since 1874 . In contrast to previous work, we find that the constriction where the valley narrows and bedrock lithology changes, $21 \mathrm{~km}$ from the terminus, represents the upper limit of surging, with negligible surface speed or elevation change up-glacier from this location. This positions the entire surge-type portion of the glacier in the ablation zone. The constriction geometry does not act as the dynamic balance line, which we consistently find at $8 \mathrm{~km}$ from the glacier terminus. During the 2012-2014 surge event, the average lowering rate in the lowest $21 \mathrm{~km}$ of the glacier was $9.6 \mathrm{~m} \mathrm{a}^{-1}$, while during quiescence it was $1.0 \mathrm{ma}^{-1}$. Due to reservoir zone refilling, the ablation zone has a positive geodetic balance in years immediately following a surge event. An active surge phase can result in a strongly negative geodetic mass balance over the surge-type portion of the glacier.
\end{abstract}

KEYWORDS: glacier hazards, glacier surges, ice dynamics, remote sensing

\section{INTRODUCTION}

Glacier surges are short periodic episodes of rapid glacier flow that are driven by internal instabilities and bracketed by longer periods of slow flow (Meier and Post, 1969). While much research has focused on understanding surging mechanisms (Meier and Post, 1969; Raymond, 1987; Harrison and Post, 2003; Qiu, 2017), surge dynamics are not yet fully understood, partially due to a lack of repeat observations of multiple surge events for the same glacier. In addition, surging behavior varies widely between glaciers, and even for repeat surges of the same glacier (Harrison and others, 1994; Björnsson and others, 2003).

Although $<1 \%$ of glaciers worldwide exhibit surge behavior (Sevestre and Benn, 2015), Alaska and western Canada are home to 113 confirmed surge-type glaciers, the third highest number after Svalbard and Pamirs (Post, 1969; Clarke and others, 1986; Kotlyakov and others, 2010; Sevestre and Benn, 2015). In the Canadian portion of the St. Elias Mountains, $\sim 6.4 \%$ of 2356 glaciers are surge-type (Clarke and others, 1986). The Yukon hosts surge-type glaciers with a wide variety of dynamic characteristics, including surge phases of up to several years and 12-50+ year repeat intervals (e.g. Donjek and Lowell Glaciers: Bevington and Copland, 2014; Abe and others, 2016; Steele Glacier: Clarke and others, 1986) and slow surges with surge phases that last several decades and surge speeds $<50 \mathrm{~m} \mathrm{a}^{-1}$ (e.g. Trapridge Glacier: Clarke and Blake, 1991; unnamed Glacier: De Paoli and Flowers, 2009). Many of the glaciers in this region are classified as polythermal (Jarvis and Clarke, 1975) and overlay soft basal sediments (Clarke and others, 1986; Harrison and Post, 2003; Crompton and Flowers, 2016; Crompton and others, 2018). Both these aspects have been suggested to be conducive to surge behavior (Hamilton and Dowdeswell, 1996; Jiskoot and others, 2000; Truffer and others, 2000). Glaciers with polythermal regimes typically exhibit slower surge development with lower peak velocities and longer surge intervals than their temperate counterparts (Clarke and Collins, 1984; Murray and others, 2003; Frappé and Clarke, 2007). Therefore, fewer repeat surge events have been observed for polythermal glaciers, limiting the understanding of surge mechanisms and initiation triggers (Murray and others, 2003; Bevington and Copland, 2014), structural development, speed-up magnitudes and advance patterns Jiskoot and others, 2001; King and others, 2015; Quincey and others, 2015; Herreid and Truffer, 2016), glacial land system development (Schomacker and others, 2014) and climate controls on surging (Eisen and other, 2001; Jiskoot and Juhlin, 2009; Flowers and others, 2011).

Surges are thought to initiate when a buildup of ice in a reservoir zone steepens the local surface slope at the dynamic balance line, or the location through which mass moves to the receiving zone but experiences no net elevation change (Dolgoushin and Osipova, 1975), until it reaches a critical basal shear stress. When the slope-steepening increases the gravitational driving stress above the critical basal shear stress, the subglacial hydrologic system rapidly evolves and surging occurs (Meier and Post, 1969; Raymond, 1987). In the classic surge cycle a surge will propagate down glacier from a reservoir zone where mass 
has built-up (Meier and Post, 1969). This type of surging has been observed at several surge-type glaciers in YukonAlaska, including Bering (Roush and others, 2003), Trapridge (Clarke and others, 1984; Frappé and Clarke, 2007) and Variegated (Kamb and others, 1985) Glaciers, as well various glaciers in Svalbard (Murray and others, 1998, 2000; Dowdeswell and Benham, 2003; Sund and others, 2009; Mansell and others, 2012), East Greenland (Jiskoot and Juhlin, 2009) and the Karakoram (Quincey and others, 2015). However, some tidewater glacier surges in Svalbard have been observed to propagate up-glacier (Rolstad and others, 1997; Luckman and others, 2002; Dowdeswell and Benham, 2003; Murray and others, 2003; Dunse and others, 2015; Flink and others, 2015; Sevestre and others, 2018). Up-glacier surge propagation has been observed elsewhere as well, including at Sabche Glacier, Nepal (Lovell and others, 2018). Both up- and down-glacier surge propagation has also been observed, such as at Sortebræ in Greenland (Murray and others, 2002).

Mass redistribution through increased ice flow is a key characteristic of surging (Meier and Post, 1969). Surge events cause a short-term redistribution of mass from the reservoir zone, across the dynamic balance line (Dolgoushin and Osipova, 1975), into the receiving zone (Meier and Post, 1969). Long-term changes in climate and associated glacier mass balance can cause glaciers to either become or cease to be of surge-type, or alter the number of surges within a region (Dowdeswell and others, 1995; Copland and others, 2011) or the individual glacier surge recurrence interval (Eisen and others, 2001). As such, it is critical that the mass balance of glaciers prior to and during surge events and the location of the dynamic balance line with respect to the equilibrium line altitude are well understood.

To better understand mechanisms of and controls on glacier surging, we reconstruct all surge events of Donjek Glacier from 1935 to present using aerial photography and satellite image archives. The primary goal of this analysis is to test the hypothesis by Abe and others (2016) that a valley constriction $\sim 20 \mathrm{~km}$ from the terminus controls the surging of the glacier by causing ice to locally thicken. For this purpose, we measure long-term changes in terminus position, surface velocity, ice elevation and surface slope, and temporally constrain the velocity patterns before, during, and after surge events in 2000-2002 and 2012-2014. These measurements provide information concerning the drivers of surge initiation and termination and enable the quantification of mass movement during surge events. Finally, we compare the surge kinematics, including the dynamic balance line location, reservoir and receiving zone length, and elevation change, to other glaciers around the world.

\section{STUDY REGION}

Donjek Glacier $\left(61^{\circ} 11^{\prime} 14^{\prime \prime} \mathrm{N}, 139^{\circ} 31^{\prime} 30^{\prime \prime}\right.$ W; Fig. 1) is located in the St. Elias Mountains of southwest Yukon. In 2010, the glacier was $65 \mathrm{~km}$ long and had an area of 448 $\mathrm{km}^{2}$ (RGI Consortium, 2017). Using a WorldView digital elevation model (DEM) from 2013 and the RGI outline, we find that the glacier surface elevations range from $\sim 1000 \mathrm{~m}$ a.s.l. at the terminus to $4507 \mathrm{~m}$ a.s.l. at the peak of Mount Walsh. In the 21 st century the late-summer snowline has gradually increased in elevation from $\sim 2430 \mathrm{~m}$ a.s.l. in 2004 to $\sim 2550$ m a.s.l. in 2017, as measured in repeat Landsat imagery. Larsen and others (2015) found that Donjek Glacier had an area-averaged negative mass balance of $-0.29 \mathrm{~m}$ w.e. $\mathrm{a}^{-1}$, or $-0.13 \mathrm{Gt} \mathrm{a}^{-1}$, between May 2000 and May 2012.

Denton and Stuiver (1966) used $\mathrm{C}^{14}$ age dating to determine that Donjek Glacier receded from Kluane Lake $(35 \mathrm{~km}$ to the northeast) 9800 years ago and its youngest major neoglacial advance occurred pre-1874 (Fig. 2). Previous research on Donjek Glacier has recorded six surge events since 1935, namely in 1935, 1978, 1969, 1989, 2001 and 2013 (Denton and Stuiver, 1966; Johnson and others, 1972a, 1972b; Clarke and Holdsworth, 2002; Abe and others, 2016). Since at least 1874 Donjek Glacier has periodically dammed the Donjek River during surge events, each time culminating in a post-surge outburst flood that endangers downstream infrastructure along the Alaska Highway (Clarke and Mathews, 1981). The most recent surge of Donjek, in 2013, caused the terminus to increase in area by nearly $2 \mathrm{~km}^{2}$ and move at a rate of $\sim 3 \mathrm{~m} \mathrm{~d}^{-1}$ over the lowest $5 \mathrm{~km}$ (Abe and others, 2016).

\section{METHODS}

\subsection{Maximum surge terminus position mapping}

We used aerial photographs and satellite imagery to reconstruct the timing of surge events since 1937 and to digitize past terminus extents (Table 1). Terminus positions were manually mapped from georeferenced images in a geographic information system. Vertical aerial photographs from 1947 were originally acquired by the Royal Canadian Air Force and obtained from the Canadian National Air Photo Library (Ottawa) and Yukon Energy, Mines, and Resources Library (Whitehorse). Vertical and oblique photos from the collections of Bradford Washburn and Austin Post provided coverage from the 1930s and 1960s, respectively (Table 1 ). We used two WorldView-2 images (Table 1) to manually georectify vertical aerial photographs with at least eight tie points each. The root mean square error of the georectified images ranged from 17.2 to $114 \mathrm{~m}$. We used 99 Landsat 2-8 images from Earth Explorer (https://earthexplorer.usgs.gov) to map terminus position change during surge events from 1977 to 1979,1988 to 1990, 2000 to 2002 and 2012 to 2014 surge events. Four scenes of the entire Landsat record were used to delineate maximum terminus position after the four most recent surge events (Table 1). We conservatively estimate our maximum uncertainty to be 2 pixel lengths or $120 \mathrm{~m}$ for Landsat 2, $60 \mathrm{~m}$ for Landsat 5 and $30 \mathrm{~m}$ for Landsat 7 and 8 .

\subsection{Elevation extraction and elevation change mapping}

We created or obtained DEMs for 2000 to 2017 from Operation IceBridge (OIB) LiDAR swaths, Satellite Pour l'Observation de la Terre 5 (SPOT-5), WorldView and Advanced Spaceborne Thermal Emissions and Reflection Radiometer (ASTER; Table 2). The LiDAR tracks from 2000, 2012 and 2016 were downloaded from the National Snow and Ice Data Center (https://nsidc.org/icebridge/portal), and down-sampled to $8 \mathrm{~m}$ resolution for comparison with other datasets. The 2000 OIB fixed LiDAR flight line deviated slightly from the glacier centerline, so we used the location of this line for comparisons with other swath LiDAR datasets 


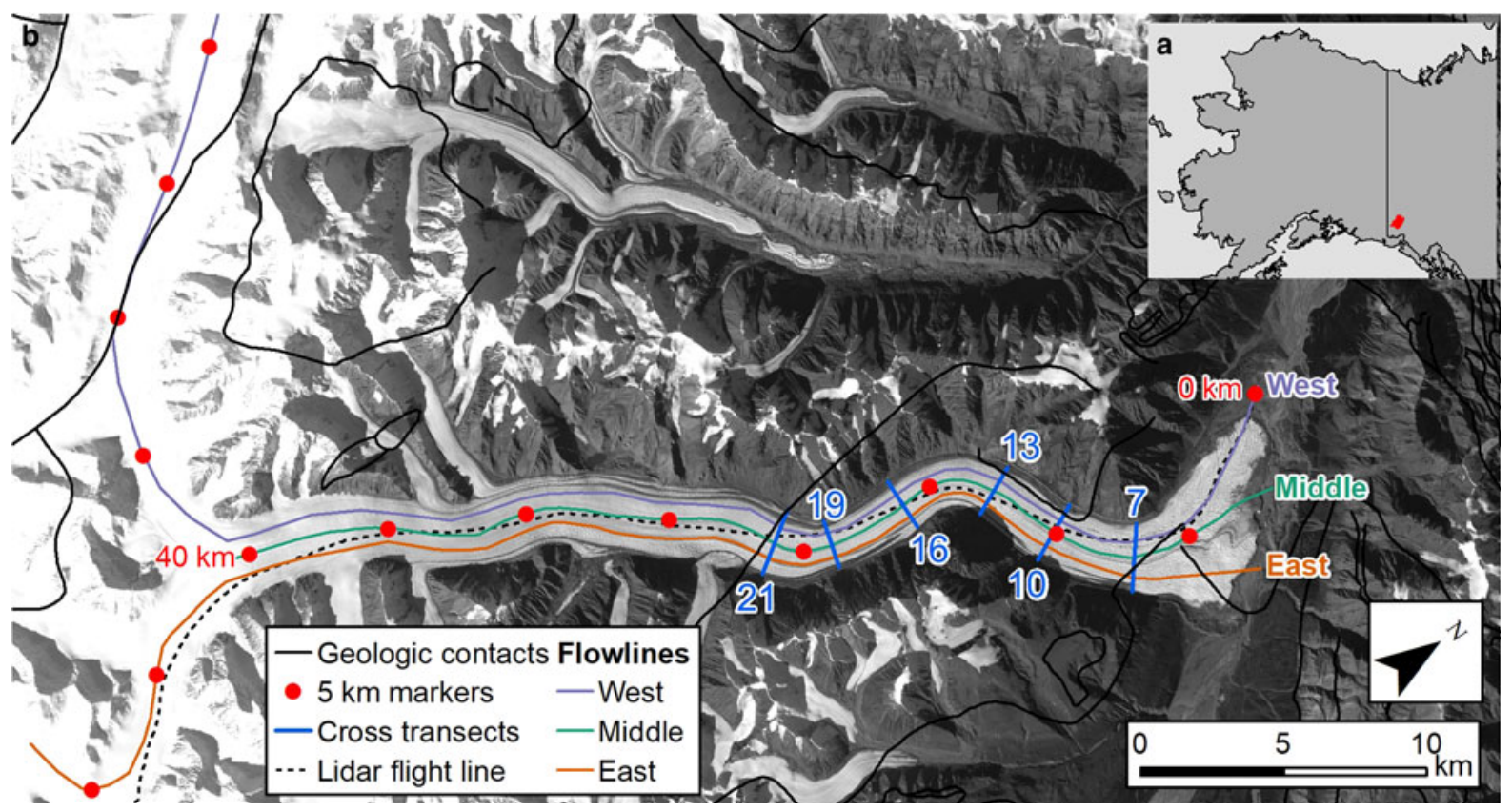

Fig. 1. Donjek Glacier flowlines and location $\left(61^{\circ} 11^{\prime} \mathrm{N}, 139^{\circ} 32^{\prime} \mathrm{W}\right)$. (a) Donjek location in southern Yukon, Canada indicated in red. (b) Tributary flowlines for the west (purple line), middle (green line) and east (orange line). We show the LiDAR flight line flown by Operation IceBridge (black dashed line), glacier transects (blue lines), geologic contacts (Yukon Geological Survey, 2018; black solid line) and 5 km markers (red dots). In 2017, the snowline was located the 40 km marker. Base image from 23 September 2017.

(Fig. 1). The 2000 OIB LiDAR flight made elevation measurements every $\sim 1.75 \mathrm{~m}$ beneath the flight path. The 2012 and 2016 OIB datasets cover a swath width of $\sim 500 \mathrm{~m}$ perpendicular to the flight path with a spatial resolution of one point per $\sim 0.4 \mathrm{~m}^{2}$. All LiDAR swaths were down-sampled to $8 \mathrm{~m}$ resolution for comparison with other datasets. We downloaded one SPOT 5 DEM from the SPIRIT Project (https://theia-landsat.cnes.fr) with an uncertainty of $\pm 6 \mathrm{~m}$ (Korona and others, 2009) from 13 September 2007 at $40 \mathrm{~m}$ spatial resolution. We obtained 2 m-resolution DEMs derived from WorldView stereo pairs from the University of Minnesota Polar Geospatial Center (PGC), with an estimated $3 \mathrm{~m}$ vertical accuracy (Noh and Howat, 2015). We mosaicked the individual WorldView DEMs from 10 August and 27 September 2013 (hereby referred to as the August/September 2013 DEM, down-sampled to $8 \mathrm{~m}$ spatial resolution), captured during the 2012-2014 surge event, to create a more spatially extensive DEM of the glacier. These DEM strips do not overlap; thus, we are unable to quantify the potential aliasing of melt and/or glacier flow on the accuracy of these measurements. Finally, we made DEMs from ASTER imagery using the software package MMASTER at $10 \mathrm{~m}$ vertical uncertainty and $30 \mathrm{~m}$ horizontal resolution for 2001, 2002 and 2003 (Girod and others, 2017). We vertically co-registered SPOT and ASTER DEMs to the WorldView DEMs using overlapping bedrock elevations. All DEMs were then smoothed using a $300 \mathrm{~m}$ moving window to better visualize the data without removing large-scale patterns. We assumed that pixel uncertainties are independent (i.e. random error) and there is no systematic bias in the change in height. The areaaveraged elevation uncertainties were calculated as $1.96 \sigma / \sqrt{L / C}$ (height change) or $1.96 \sigma A / \sqrt{A / C^{2}}$ (volume change) where $\sigma$ is the std dev. for on ice measurements. In these equations $A$ is the area of coverage, $L$ is the length of coverage and $C$ is the autocorrelation length $(500 \mathrm{~m}$;
Howat and others, 2008; McNabb and others, 2019). We calculated volume change by multiplying the profile average elevation change by the glacier zone area.

\subsection{Ice velocity mapping}

We used Landsat 7 and 8 panchromatic images (Band 8) from Earth Explorer and Radarsat-2 amplitude images to measure glacier velocity (Table 3). After manually inspecting optical images for cloud cover, we used the Ames Stereo Pipeline to cross correlate panchromatic scenes to measure ice displacement (Shean and others, 2016) using the Extreme Science and Engineering Discovery Environment computing resources (Towns and others, 2014). We used a custom Python script (Derek Mueller, pers. comm.) to convert RADARSAT-2 ultrafine wide ( $\sim 2.2 \mathrm{~m}$ resolution) level-0 raw data to amplitude images. We then processed image pairs acquired in subsequent 24-day orbits using the AMES stereo pipeline (Shean and others, 2016). Landsat 1, 2, and 5 scenes were visually assessed using manual feature tracking (e.g. on looped moraines) to observe glacier velocity increase (decrease) at the start (end) of a surge event as automated velocity mapping yielded results with high uncertainties. We correlated every image without major cloud cover for each year, and smoothed the resulting velocity profiles using a moving window of $300 \mathrm{~m}$ (Fig. 1). To assess the precision of our measurements, we measured the apparent motion over nonglacierized terrain (i.e. static objects) for each velocity map. First, we discarded values above $1800 \mathrm{~m} \mathrm{a}^{-1}$, which we considered indicative of false matches (e.g. due to variations in snow cover), as these exceeded the highest glacier motion measured during the study period. We then computed the mean apparent velocity of the remaining area surrounding Donjek Glacier that is not currently glacierized to obtain uncertainty estimates ranging from 17.0 to $155.1 \mathrm{~m} \mathrm{a}^{-1}$ (Table 3). 


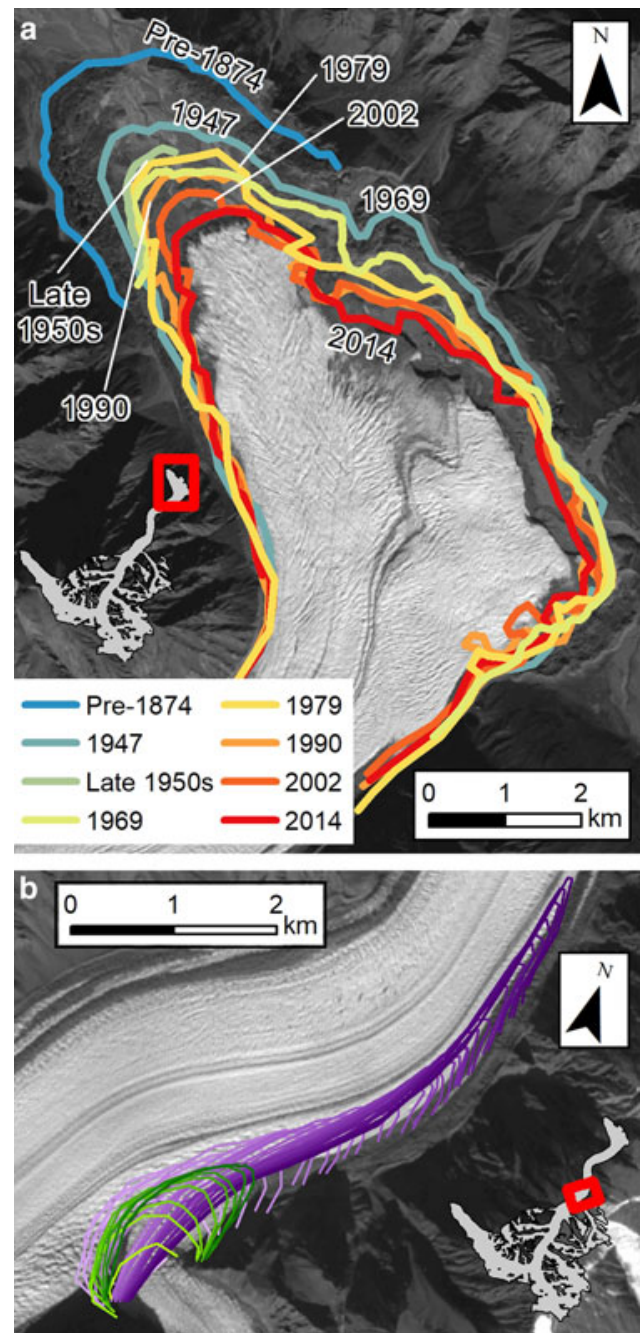

Fig. 2. Donjek Glacier maximum surge extent. (a) Most advanced terminus position after each surge event from 1847 (little ice age extent; dark blue) to 2014 (dark red). Base image from 23 September 2017 panchromatic band (Landsat 8). (b) Extent of the Donjek Glacier tributary after 1974 (purple) and 2010 (green) surge events. Tributary extent digitized from 1972 (light purple) to 2009 (dark purple) and 2010 (light green) to 2017 (dark green). Base image from 18 May 2017.
Table 2. Elevation data sources for ice surface change

\begin{tabular}{lcl}
\hline Source & \multicolumn{1}{c}{ Date } & \multicolumn{1}{c}{$\begin{array}{c}\text { Vertical } \\
\text { uncertainty }\end{array}$} \\
\hline $\begin{array}{l}\text { Operation IceBridge, air- } \\
\text { borne lidar }\end{array}$ & $30 / 05 / 200022 / 05 / 2012$ & $<10 \mathrm{~cm}$ \\
ASTER (satellite) & $15 / 05 / 2016$ & \\
& $28 / 09 / 200126 / 05 / 2002$ & $10 \mathrm{~m}$ \\
PGCMorldView & $01 / 08 / 2003$ & \\
(satellite) & $10 / 08 / 201327 / 09 / 2013$ & $\sim 0.2 \mathrm{~m}$ \\
SPOT (satellite) & $13 / 09 / 2007$ & $6 \mathrm{~m}$ \\
\hline
\end{tabular}

\section{RESULTS}

\subsection{Surge initiation, termination and timing}

Surge initiation can be measured by terminus advance, velocity increase, crevasse formation and/or surface elevation change (Meier and Post, 1969; Raymond, 1987; Sund and others, 2009) each with a different date and uncertainty range. We quantified the surge initiation of Donjek Glacier by the first record of terminus advance or up-glacier velocity increase. Similarly, surge termination was defined by the first terminus retreat or velocity decrease. We consider the terminus to have advanced (retreated) when the glacier area increased (decreased) outside the terminus delineation uncertainty. We are not able to discern why or how the terminus retreated although possible mechanisms include ice melt, increasing debris cover appearing as bedrock or moraine material in satellite imagery, or if ice was melted or carried away by Donjek River. We report uncertainties in surge timing based on velocity and terminus position change where the uncertainty in active or quiescent phase length is due to satellite image availability. Based on our analysis of historical aerial photography and satellite imagery, we independently confirmed that surge events took place during the years $\sim 1935$ (Denton and Stuiver, 1966), late1950s, 1969, 1978 (Clarke and Holdsworth, 2002), 1989, 2001 and 2013 (Abe and others, 2016).

The 1937 oblique photograph from Bradford Washburn shows glacial morphology consistent with a recent surge,

Table 1. Aerial photographs and images used for terminus delineation in this study

\begin{tabular}{|c|c|c|c|c|}
\hline Date & Image ID & $\begin{array}{l}\text { Resolution } \\
\text { (m) }\end{array}$ & Source & Photographer/sensor \\
\hline 14 August 1937 & wb0516 & Oblique & UAF & Bradford Washburn \\
\hline 24 July 1947 & A11002-274 & 1.0 & Yukon EMR & Royal Canadian Air Force \\
\hline 24 July 1947 & A11002-275 & 1.5 & Yukon EMR & Royal Canadian Air Force \\
\hline 25 July 1947 & A11014-255 & 1.5 & NAPL & Royal Canadian Air Force \\
\hline 10 August 1961 & 1961_PHColl734.YD24 & Oblique & ASF & Austin Post \\
\hline 27 August 1969 & AP69V2_226 & 0.60 & ASF & Austin Post \\
\hline 6 August 1979 & LM02L1TP06701719790806 & 60 & $\mathrm{EE}$ & Landsat 2 \\
\hline 14 August 1990 & LT05L1TP06101719900814 & 30 & $\mathrm{EE}$ & Landsat 5 \\
\hline 26 May 2002 & LE07L1TP06201720020526 & 15 & $\mathrm{EE}$ & Landsat 7 \\
\hline 2 September 2012 & WV02_20120902205854 & 0.56 & PGC & WorldView-2 \\
\hline 2 September 2012 & WV02_20120902205951 & 0.49 & PGC & WorldView-2 \\
\hline 3 May 2014 & LC08L1TP06201720140503 & 15 & $\mathrm{EE}$ & Landsat 8 \\
\hline
\end{tabular}

UAF, University of Alaska Fairbanks Elmer E. Rasmuson Library; Yukon EMR, Yukon Energy, Mines, and Resources Library, Whitehorse; NAPL, National Air Photo Library, Ottawa; ASF, Alaska Satellite Facility; EE, United States Geological Survey Earth Explorer; PGC, Polar Geospatial Center at University of Minnesota. 
Table 3. Landsat (L) 5, 7, 8, and Radarsat-2 (R2) scenes used to determine glacier velocities with associated uncertainty measured by movement of surrounding nonglacierized terrain

\begin{tabular}{|c|c|c|c|}
\hline Satellite & First scene & Second scene & $\begin{array}{l}\text { Mean/SD velocity } \\
\text { over nonglacierized } \\
\text { terrain }\left(\mathrm{m} \mathrm{a}^{-1}\right)\end{array}$ \\
\hline L5 & 04/05/1988 & $21 / 06 / 1988$ & $81.7 / 200.0$ \\
\hline L5 & 21/06/1988 & $23 / 07 / 1988$ & $65.8 / 137.1$ \\
\hline L5 & 23/07/1988 & 09/09/1988 & $46.2 / 135.9$ \\
\hline L5 & 08/06/1989 & 11/08/1989 & $76.3 / 230.7$ \\
\hline L5 & 08/11/1989 & 28/09/1989 & $92.2 / 262.2$ \\
\hline L5 & 13/07/1990 & 14/08/1990 & $45.7 / 150.3$ \\
\hline L5 & 23/07/1991 & 25/09/1991 & $42.0 / 176.4$ \\
\hline L7 & 05/07/1999 & 29/08/1999 & $43.9 / 89.3$ \\
\hline L7 & 17/08/2000 & $18 / 09 / 2000$ & $67.3 / 129.0$ \\
\hline L7 & 27/03/2001 & $28 / 04 / 2001$ & 73.1/134.6 \\
\hline L7 & 16/05/2001 & 19/07/2001 & $53.7 / 116.2$ \\
\hline L7 & 19/07/2001 & $20 / 08 / 2001$ & 68.0/105.5 \\
\hline L7 & 16/03/2002 & $03 / 05 / 2002$ & $62.1 / 106.7$ \\
\hline L7 & 03/05/2002 & $26 / 05 / 2002$ & $155.1 / 232.4$ \\
\hline L7 & $26 / 05 / 2002$ & 05/08/2002 & $49.0 / 90.9$ \\
\hline L7 & 05/08/2002 & $22 / 09 / 2002$ & $48.5 / 103.0$ \\
\hline R2 & $24 / 02 / 2012$ & $19 / 03 / 2012$ & $62.4 / 51.7$ \\
\hline L7 & 18/03/2012 & $19 / 04 / 2012$ & $90.1 / 146.1$ \\
\hline L7 & 19/04/2012 & 06/06/2012 & $67.8 / 163.0$ \\
\hline L7 & 06/06/2012 & 08/07/2012 & $63.8 / 134.3$ \\
\hline L7 & 21/03/2013 & $22 / 04 / 2013$ & $124.7 / 170.2$ \\
\hline L8 & 02/04/2013 & $23 / 05 / 2013$ & $44.9 / 102.0$ \\
\hline L8 & $23 / 05 / 2013$ & $24 / 06 / 2013$ & $48.2 / 126.0$ \\
\hline L8 & $24 / 06 / 2013$ & $11 / 08 / 2013$ & $21.9 / 65.9$ \\
\hline L8 & $11 / 08 / 2013$ & $27 / 08 / 2013$ & $59.2 / 156.6$ \\
\hline R2 & $20 / 02 / 2014$ & $16 / 03 / 2014$ & $28.4 / 59.7$ \\
\hline L8 & $25 / 03 / 2014$ & $10 / 04 / 2014$ & $61.7 / 130.6$ \\
\hline L8 & 10/04/2014 & $26 / 04 / 2014$ & $125.8 / 200.1$ \\
\hline L8 & $26 / 04 / 2014$ & $04 / 06 / 2014$ & $54.5 / 108.8$ \\
\hline L8 & 04/06/2014 & $22 / 07 / 2014$ & $31.7 / 89.1$ \\
\hline L8 & $22 / 07 / 2014$ & $23 / 08 / 2014$ & $17.0 / 60.9$ \\
\hline L8 & $23 / 08 / 2014$ & $15 / 09 / 2014$ & $64.7 / 127.1$ \\
\hline
\end{tabular}

Date format is $\mathrm{dd} / \mathrm{mm} / \mathrm{yyyy}$.

independently confirming an observation of an 1935 surge event by Johnson and others (1972a). We additionally observed geomorphology consistent with an active surge phase in 1947 aerial photographs from the Royal Canadian Air Force (e.g. debris-free, advancing margin and small push moraines), suggesting that a surge initiated sometime within 2 years prior to 1947 . While Johnson (1972a) states there was a surge in 1961, examination of glacial geomorphic features (e.g. push moraines) in Austin Post's oblique photographs from 1961 suggest that a surge event had recently occurred but that the glacier was not actively surging at that time.

The 1977-1979 surge event was characterized by an increase in glacier velocity, followed by an active phase of $\sim 2-3$ years before the velocity decreased and terminus retreated. The surge initiated when the up-glacier velocity increased between 11 June and 28 July 1977 in the lower $21 \mathrm{~km}$ of the glacier (Fig. 3; Table 2). The terminus then began to advance between 28 July and 17 August 1977 (Fig. 3). The terminus began to retreat and the ice velocity returned to quiescent values between 28 August 1979 and 12 May 1980 (Fig. 3; Table 2). The active phase of the 1977-1979 surge therefore lasted 2.08-2.92 years.

The 1988-1990 surge event started with terminus advance followed by velocity increase up-glacier and an active phase of $\sim 2$ years before the velocity decreased and finally the terminus retreated. The event initiated when the terminus began to advance between 6 and 23 August 1988 (Fig. 3; Table 4). The up-glacier velocity began to increase following terminus advance, between 9 September 1988 and 8 June 1989 (Fig. 3). We measured a peak velocity of $850 \pm 76 \mathrm{~m} \mathrm{a}^{-1}$ between 8 June 1989 and 11 August 1989; however, Landsat images are not available to provide more temporally constrained velocity observations, so we are not confident this was the maximum velocity for the surge event. Velocity measurements from 1988 to 1990 show that the surge event was limited to a velocity increase in the lower $21 \mathrm{~km}$ of the glacier. The velocity data suggest the glacier had returned to its quiescent phase between 29 July and 14 August 1990 and the terminus began to retreat between 6 August and 1 October 1990 (Fig. 3; Table 4). The active phase of the 1988-1990 surge therefore lasted $1.97-2.15$ years.

The 2000-2002 surge event began with terminus advance followed by an increase in up-glacier velocities and an active phase of $\sim 2$ years. The surge ended when the terminus began to retreat then the glacier velocities returned to quiescence. The active phase started with a small advance of the glacier terminus along the middle and eastern segments between 1 August and 18 September 2000 (Fig. 3; Table 4). We first observed up-glacier velocity increase between 18 September 2000 and 28 April 2001 (Figs 3, 4), when the velocity approximately doubled over the entire $\sim 15 \mathrm{~km}$ upglacier from the terminus (Fig. 4). Velocities then increased by an order of magnitude in the lowest $18 \mathrm{~km}$ from 16 May to 19 July 2001 compared to quiescence (Figs 3, 4). However, velocities did not peak until 19 July to 20 August 2001 (Figs 3, 4). The 2001 surge termination started with a decrease in ice motion between 21 and 28 September 2001 (Fig. 3). The decrease in velocity was particularly pronounced $8-10 \mathrm{~km}$ from the terminus, where velocities decreased by as much as $50 \%$ along the middle flowline. We then observed terminus retreat between 14 October 2001 and 23 March 2002 (Fig. 3). However, velocities did not return to quiescent values ( $<100 \mathrm{~m} \mathrm{a}^{-1}$ at the terminus) until 5 August to 22 September 2002 (Figs 3, 4; Table 4). The active phase of the 2000-2002 surge event therefore lasted 1.87-2.14 years (Table 4 ).

The 2012-2014 surge event initiated when up-glacier glacier velocities increased followed by terminus advance and an active phase of $\sim 1.5$ years. This was followed by a decrease in glacier velocities and finally terminus retreat to mark full surge termination. The first indicator of the 20122014 surge event occurred between 6 June and 8 July 2012 (Figs 3-5; Table 4) as velocity increased by as much as $\sim 200 \%$ within the entire zone up to $15 \mathrm{~km}$ from the terminus. The terminus began to advance between 8 July 2012 and 21 March 2013 (Figs 3, 4). However, we did not measure velocities an order of magnitude greater than quiescence until 21 March to 22 April 2013 (Fig. 3). Velocities peaked during the 2012-2014 surge event between 23 May and 24 June 2013 (Figs 3-5). We first observed a decrease in velocity between 24 June and 11 August 2013 in the lowest $21 \mathrm{~km}$ of Donjek (Fig. 3). The last period of observed velocities at least an order of magnitude above quiescent velocities was 11 August to 27 August 2013 (Fig. 3). Over the next year, velocity decreased until it returned to a quiescent rate between 22 July and 23 August 2014 (Figs 3-5). We first observed terminus retreat between 16 October 2013 and 12 February 


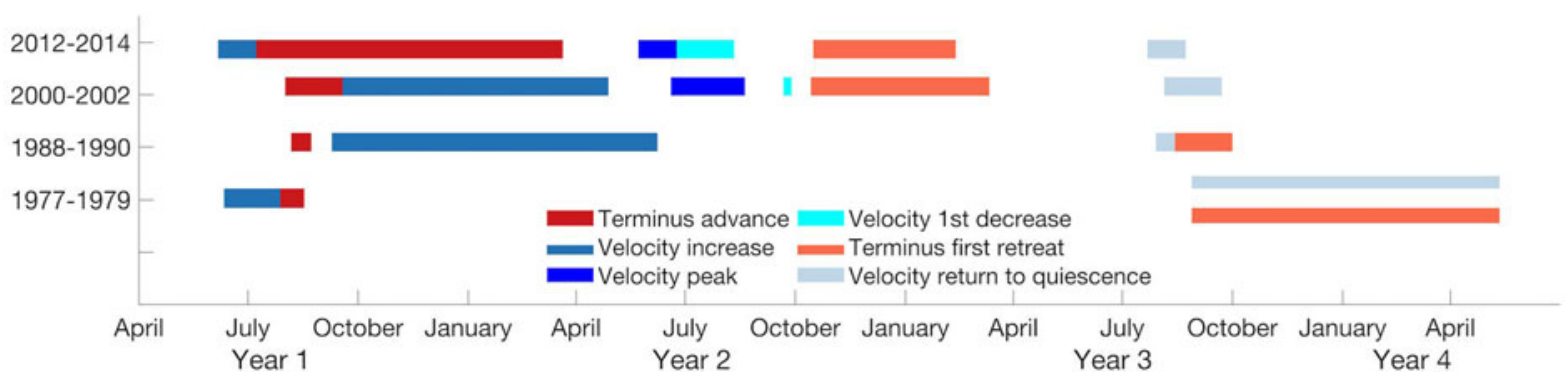

Fig. 3. Surge timing. Surge characteristics are shown for the 1977-1979, 1988-1990, 2000-2002 and 2012-2014 surge events. Periods of terminus advance (red), when the up-glacier velocity is first observed to increase (medium blue), peak observed velocity (dark blue), when velocity is first observed to decrease (cyan), when the velocity returns to quiescent levels (gray) and terminus retreat (light red) are shown. The temporal width of bars is indicating the temporal uncertainty of the observation, bookended by two satellite observations. Years $1-4$ on the $x$-axis indicate the year of the surge (e.g. year 1 of the 1977-1979 surge event is 1977, year 3 is 1979).

2014 (Fig. 3; Table 4). The active phase of the 2012-2014 surge therefore lasted $1.28-1.69$ years (Table 4 ).

In contrast to previous studies (Clarke and Holdsworth, 2002; Abe and others, 2016) on Donjek Glacier we find that the active surge phase duration is between 1.28 and 2.15 years, and the quiescent phase duration between 9.0 and 10.17 years, for the well-defined events since the 1970s (Table 4). The surge recurrence interval was $\sim 12$ years between the first four observed surges ( 1935,

Table 4. Date of transition between active (A) and quiescent (Q) phases for Donjek Glacier, based on changes in terminus position and velocity

\begin{tabular}{|c|c|}
\hline Date of phase transition & Active/quiescent phase and duration \\
\hline \multirow{2}{*}{$\sim 1935$} & $\mathrm{Q}_{0}$ \\
\hline & $\mathrm{A}_{1}(\sim 2$ years $)$ \\
\hline$\sim 1935$ & $\mathrm{Q}_{1}(\sim 10$ years $)$ \\
\hline$\sim 1947$ & $\mathrm{~A}_{2}(\sim 2$ years $)$ \\
\hline 1947 & $\mathrm{Q}_{2}(\sim 10$ years $)$ \\
\hline Late-1950s & $\mathrm{A}_{3}(\sim 2$ years $)$ \\
\hline Late-1950s & $\mathrm{Q}_{3}(\sim 10$ years $)$ \\
\hline$\sim 1969$ & $\mathrm{~A}_{4}(\sim 2$ years $)$ \\
\hline$\sim 1969$ & $\mathrm{Q}_{4}(\sim 7$ years $)$ \\
\hline 11/06/1977-28/07/1977 & $\mathrm{A}_{5}(2.08-2.92$ years $)$ \\
\hline 28/08/1979-12/05/1980 & $\mathrm{Q}_{5}(8.24-8.99$ years $)$ \\
\hline 06/08/1988-23/08/1988 & $\mathrm{A}_{6}(1.97-2.15$ years $)$ \\
\hline 14/08/1990-01/10/1990 & $\mathrm{Q}_{6}(9.86-10.11$ years $)$ \\
\hline 01/08/2000-18/09/2000 & $\mathrm{A}_{7}(1.87-2.14$ years $)$ \\
\hline 05/08/2002-22/09/2002 & $\mathrm{Q}_{7}$ (9.71-10.17 years) \\
\hline 06/06/2012-08/07/2012 & $\mathrm{A}_{8}(1.28-1.69$ years $)$ \\
\hline 16/10/2013-12/02/2014 & Q8 (ongoing) \\
\hline
\end{tabular}

Date format is $\mathrm{dd} / \mathrm{mm} /$ yyyy. Uncertainties in earlier years due to image availability.
1947, late-1950s and 1969), 10 years between the following three ( 1969, 1977-1979 and 1988-1990) and again $\sim 12$ years between each of the last three surge events (1988-1990, 2000-2002 and 2012-2014).

\subsection{Changes in maximum surge extent}

The terminus of Donjek Glacier retreated by $\sim 2.5 \mathrm{~km}$ between the pre-1874 Little Ice Age terminal moraines and its most recently advanced surge extent in May 2014. The rate of retreat has varied across the glacier terminus, with the fastest retreat rate of $18 \mathrm{~m} \mathrm{a}^{-1}$ over 140 years occurring along the northwest terminus (Fig. 2). Between the maximum extent of the 1947 and 2014 surges, Donjek retreated by $1.5 \mathrm{~km}$ at the northwestern terminus, at a mean rate of $22 \mathrm{~m} \mathrm{a}^{-1}$. The eastern terminus of Donjek has changed less through time, retreating at most $490 \mathrm{~m}$ between 1947 and 2014 (Fig. 2a). Between the maximum extents of two most recent surges, in 2002 and 2014, the entire terminus retreated by an average of $32 \mathrm{~m} \mathrm{a}^{-1}$. In general, the magnitude of terminus advance during surges has progressively decreased over time. An exception to this pattern is the 1978 surge event, during which the terminus advanced up to $200 \mathrm{~m}$ further than the 1969 surge event.

The only tributary of Donjek Glacier that is known to surge enters the eastern side of the main valley at a distance $\sim 23 \mathrm{~km}$ upstream of the terminus (Fig. 2b). We confirm two surges of the tributary in 1974 and 2010 from looped moraines in the main trunk of Donjek Glacier in Landsat imagery (Clarke and Holdsworth, 2002; Abe and others, 2016). From 1973 to 1975 the tributary advanced $640 \mathrm{~m}$ into the trunk of Donjek Glacier (Fig. 2b), in 2010 it had advanced $220 \mathrm{~m}$ into the trunk and by 2011 it had advanced an additional $270 \mathrm{~m}$ into the trunk. The ice then flowed toward the terminus at an average rate of $50 \mathrm{~m} \mathrm{a}^{-1}$ (Fig. 2b).

\subsection{Velocity patterns}

The highest surge velocities always occurred in the lower 10 $\mathrm{km}$ of Donjek Glacier, with increases up to two orders of magnitude from quiescence, while upstream of $15 \mathrm{~km}$ only a doubling or tripling of surge velocity relative to quiescence was observed (Figs 4, 5). In 2001 a maximum velocity of $1700 \mathrm{~m} \mathrm{a}^{-1}$ occurred within $3 \mathrm{~km}$ of the terminus and in 2013 a maximum of $1150 \mathrm{~m} \mathrm{a}^{-1}$ occurred $8 \mathrm{~km}$ upstream of the terminus (Fig. 4). The 2000-2002 surge velocities were generally higher than the 2012-2014 surge velocities, 

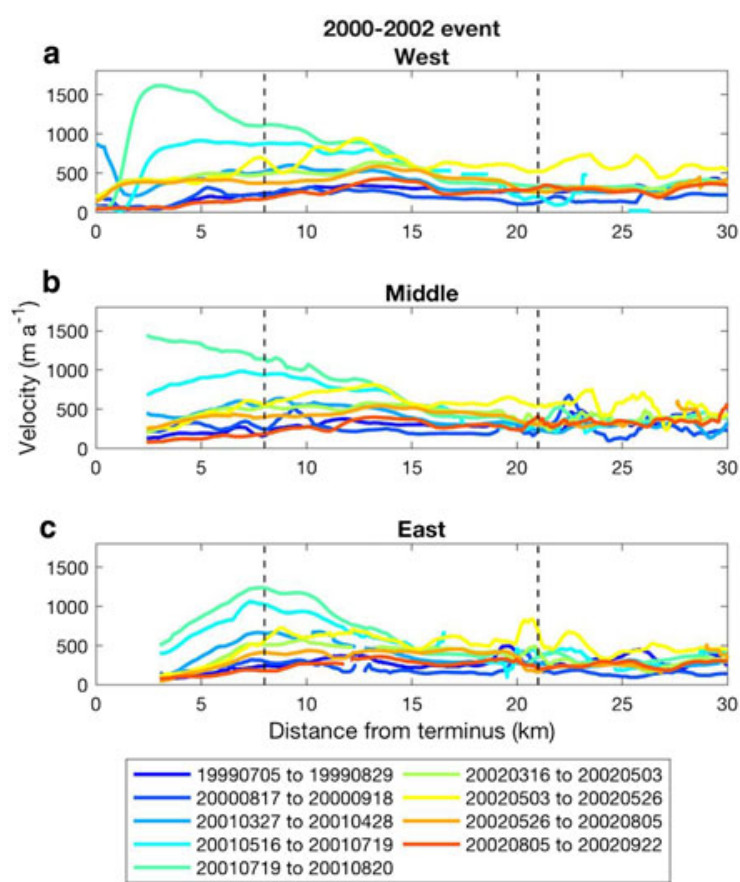
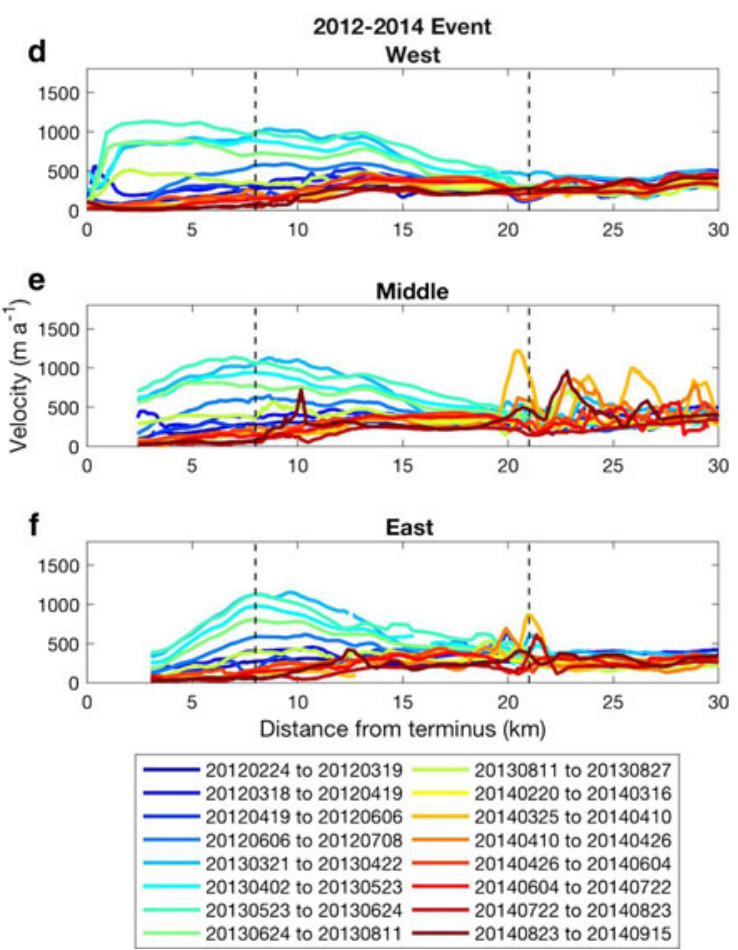

Fig. 4. Surge velocity. (a-c) Active surge phase velocity for the east, middle and west flowlines (locations on Fig. 1) during the 2000-2002 surge event. Dates for a-c are given below c. (d-f) Active surge phase velocity for the east, middle and west flowline for the 2012-2014 surge event. Dates for $\mathrm{d}-\mathrm{f}$ are given below $\mathrm{f}$. Velocity profiles are shown from blue (beginning of surge) to red (end of surge). Extent of the reservoir zone indicted by black dashed lines at 8 and $21 \mathrm{~km}$ from the terminus. Dates are presented in the YYYYMMDD format.

and near the western end of the terminus they were almost double those in 2012-2014 (Fig. 4).

Following surge initiation, velocities begin to rapidly increase below $16 \mathrm{~km}$ from the terminus (Figs 4a-f). When a surge terminated and the velocity in the lower $21 \mathrm{~km}$ of the glacier returned to that of quiescence (average $\sim 130 \mathrm{~m}$ $\mathrm{a}^{-1}$ ), we observed velocities between 21 and $30 \mathrm{~km}$ from the terminus to remain constant or slightly increase when
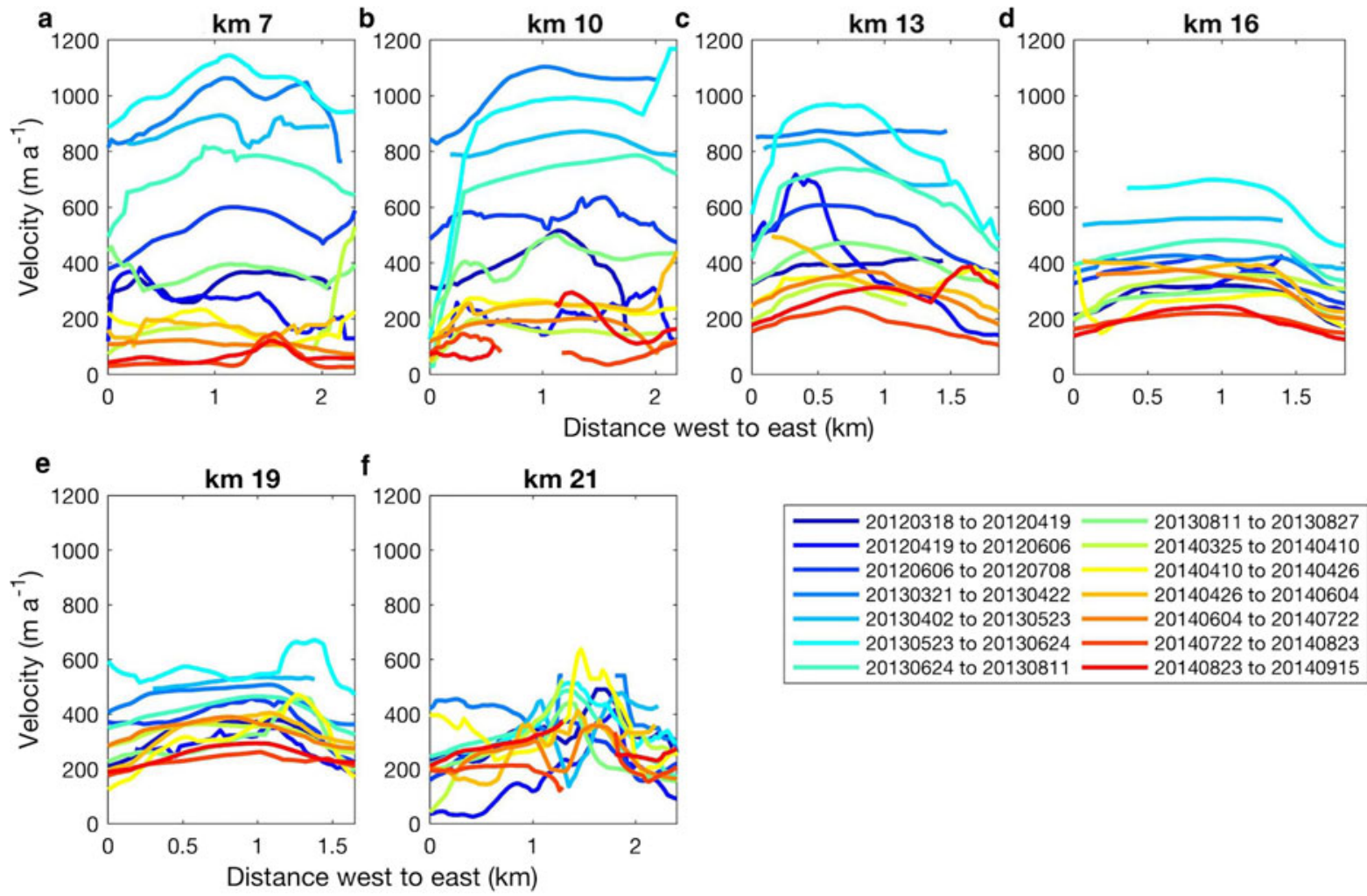

Fig. 5. 2012-2014 surge transects. (a-f) Velocity transects before, during and after surge event are shown, position of each transect shown in Figure 1, all velocities flow into page. Line color transitions from dark blue to dark red as the surge progresses. 
compared to the surge phase (Fig. 4). We were unable to reliably measure velocities $\gtrsim 30 \mathrm{~km}$ from the terminus due to transient snow cover, particularly in the accumulation zone $>40 \mathrm{~km}$ from the terminus. Velocities were elevated across the width of the glacier during surges (Fig. 5). Some profiles in the lower $13 \mathrm{~km}$ of the glacier appeared to have a slight parabolic shape with faster flow in the middle, but above $16 \mathrm{~km}$ velocity cross-sections showed nearly constant ice motion across the glacier width (Fig. 5). At $21 \mathrm{~km}$ from the terminus, velocities across the glacier width remained fairly constant throughout the surge event at $\sim 300 \mathrm{~m} \mathrm{a}^{-1}$ (ranging from $\sim 200$ to $\sim 600 \mathrm{~m} \mathrm{a}^{-1}$; Fig. 5f).

\subsection{Elevation and slope changes}

During the 2000-2002 and 2012-2014 surges of Donjek Glacier, changes in surface elevation suggest a net movement of ice mass from a $13 \mathrm{~km}$-long reservoir zone (between 8 and $21 \mathrm{~km}$ from the terminus, representing an area of $28.6 \mathrm{~km}^{2}$ ) to an $8 \mathrm{~km}$-long receiving zone (including the advanced terminus; area of $16.0 \mathrm{~km}^{2}$; Fig. 6). During the second half of the 2000-2002 surge, we observe a redistributed of ice toward the terminus between 28 September 2001 and 26 May 2002. During this period, the surface elevation of the reservoir zone (11 and $16 \mathrm{~km}$ from the terminus) lowered by an average of $1.33 \pm 8.6 \mathrm{~m}$ and locally as much as $37 \pm 14 \mathrm{~m}$, while the surface elevation of the receiving zone rose by an average of $1.8 \pm 2.6 \mathrm{~m}$ and locally as much as $52 \pm 14 \mathrm{~m}$ (Fig. 6). This does not represent the total mass displaced by the surge event, as the surge initiated before our first elevation observation in 2001 (Fig. 6).

During the 2002-2007 quiescent phase, we observed a thickening of $14.8 \pm 3.5 \mathrm{~m}\left(\sim 0.423 \pm 0.061 \mathrm{~km}^{3}\right)$ in the reservoir zone and a thinning of $20 \pm 5.7 \mathrm{~m}\left(\sim 0.32 \pm 0.059 \mathrm{~km}^{3}\right)$ in the receiving zone (Figs 7a-c, 8). From 2007 to 2013, which encompasses $\sim 5$ years of quiescence and most of a surge event, the reservoir zone lowered by an average of $21.3 \pm 2.0 \mathrm{~m}\left(\sim 0.609 \pm 0.035 \mathrm{~km}^{3}\right)$ and the receiving zone thickened by an average of $5.8 \pm 3.3 \mathrm{~m}(\sim 0.092 \pm$ $0.034 \mathrm{~km}^{3}$; Figs $\left.7 \mathrm{a}-\mathrm{c}, 8\right)$. The receiving zone thickening does include some terminus retreat from 2007 to 2013 along the western flowline (Figs 7, 8). Surface elevation changes were subtler up-glacier from the reservoir zone: from 21 to $30 \mathrm{~km}$, the ice surface lowered by an average of $3.5 \pm 1.7 \mathrm{~m}$ from 2007 to 2013 (Fig. 7). Drainage of the reservoir zone and filling of the receiving zone were not uniform across the glacier during this time period. From 2007 to 2013, we observed a maximum ice elevation increase of $44 \pm 6.7 \mathrm{~m}$ at the terminus along the middle flowline and a maximum lowering of $61 \pm 6.7 \mathrm{~m}$ at $12.2 \mathrm{~km}$ up-glacier along the west flowline.

As the mass moved during the surge event, the glacier surface slope also changed. Slope changes during quiescence were mirrored by a nearly equal and opposite slope change during the surge phase in a wave-like pattern (Fig. 7e). The wavelength is 1.5 to $2 \mathrm{~km}$ with a maximum amplitude of $2^{\circ}$ (Figs $7 \mathrm{~d}$, e). In the lower $1 \mathrm{~km}$ of the reservoir zone $(8-9 \mathrm{~km}$ from the terminus) the glacier surface slope increased from 1.1 to $2.2^{\circ}$ between 2002 and 2007 (Figs 7d, e). From 2007 to the end of the surge event in 2013, the slope over this area decreased by $1.2^{\circ}$ on average. Overall, between 2007 and 2013 the glacier absolute slope decreased from 2.30 to $2.15^{\circ}$ in the receiving zone and 2.05 to $1.8^{\circ}$ in the reservoir zone (Fig. 7). The largest glacier surface slope changes occurred at $8.5 \mathrm{~km}$ from the glacier terminus on the eastern flowline, where the slope increased by $2.5^{\circ}$ from 2002 to 2007 and decreased by $2.7^{\circ}$ from 2007 to 2013. The observed change in surface slope along the eastern flowline corresponds with a maximum elevation gain of $51 \pm 12 \mathrm{~m}$ during quiescence along the same flowline (Fig. 7c).

We measured the long-term geodetic mass balance of the lower $32 \mathrm{~km}$ of Donjek Glacier and the impact of the surge events using Operation IceBridge lidar swaths along the approximate centerline and WorldView DEMs. From 30 May 2000 to 22 May 2012, during which time a complete surge cycle occurred, the lower $32 \mathrm{~km}$ of the glacier surface lowered by an average of $1.0 \mathrm{~m} \mathrm{a}^{-1}$ (Fig. 9). During the surge, from 22 May 2012 to August/September 2013 the lower $21 \mathrm{~km}$ of the glacier surface lowered by an average of $9.6 \mathrm{~m} \mathrm{a}^{-1}$ along the flowline (Fig. 9), divided between a thickening of $6.11 \mathrm{~m}\left(\sim 0.098 \pm 0.0015 \mathrm{~km}^{3}\right)$ in the receiving zone $(0-8 \mathrm{~km}$ from terminus) and a thinning of $-21.32 \mathrm{~m}$ $\left(\sim 0.61 \pm 0.0016 \mathrm{~km}^{3}\right)$ in the reservoir zone $(8-21 \mathrm{~km}$ from terminus). If we extrapolate these results by zone area and assume constant glacier width and profile averages we find a net volume change of $-0.512 \pm 0.0022 \mathrm{~km}^{3}$. From August/September 2013 to 15 May 2016, the first three years of the current quiescent phase, the lower $32 \mathrm{~km}$ of the glacier surface rose by an average of $1.2 \pm 0.0017 \mathrm{~m}$ $\mathrm{a}^{-1}$ (Fig. 9).

From these observations, we infer the dynamic balance line to be $8 \mathrm{~km}$ upstream of the terminus. There is little change in surface elevation over time at this hinge, but there is pronounced mass movement across this line from the reservoir zone to the receiving zone during both the 2000-2002 and 2012-2014 surge events. Consistent with an inferred dynamic balance line in this location, there are significant changes in slope during surges in this area, especially along the eastern flowline (Fig. 7).

\section{DISCUSSION}

\subsection{Mass redistribution}

Abe and others (2016) hypothesized that the narrowing of the valley at $20 \mathrm{~km}$ up-glacier of the Donjek terminus acts as a constriction to outflow, allowing ice to accumulate in an upstream reservoir zone. The thickening and steepening at this location would eventually lead to the onset of a surge. Therefore, according to Abe and others (2016), the location of this constriction may be the location of the dynamic balance line. However, our velocity and elevation observations indicate that glacier velocity only increases significantly in the lowermost $21 \mathrm{~km}$ of the glacier during a surge, showing that both the reservoir and receiving zones are within this region. Indeed, we observe mass movement from a reservoir zone at $8-21 \mathrm{~km}$ from the terminus, across the dynamic balance line at $\sim 8 \mathrm{~km}$ and into the receiving zone at $0-8 \mathrm{~km}$ from the terminus. This signifies that the constriction at 21 $\mathrm{km}$ limits the up-glacier extent of the surges, where only the portion of the glacier downstream of the valley constriction exhibits true surge-type behavior. However, the role of the valley constriction is not fully understood. While we and Abe and others (2016) both suggest the constriction is crucial in controlling surging, we lack observations to determine how it controls the surges. New bed elevation and glacier surface velocity observations are needed to understand the role of the Donjek constriction in surging. 

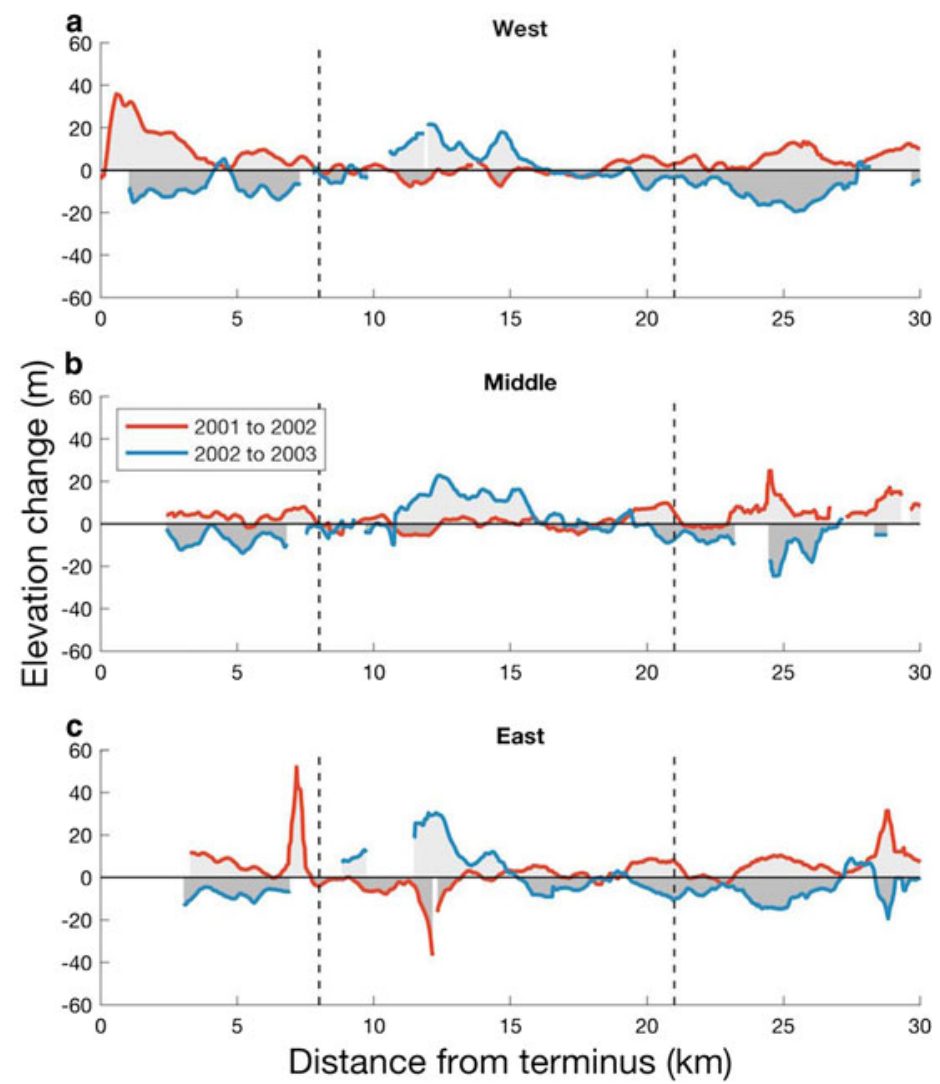

Fig. 6. 2000-2002 surge event elevation change. (a-c) Elevation change for each flowline from 28 September 2001 to 26 May 2002 and 26 May 2002 to 1 August 2003. Extent of the reservoir zone indicted by black dashed lines at $8 \mathrm{~km}$ (dynamic balance line) and $21 \mathrm{~km}$ from the terminus.

Although the region up-glacier of the constriction is not actively involved in surging, it plays a key role in refilling the reservoir zone. We observe rapid refilling of the reservoir zone following a surge event, leading to a positive geodetic mass balance over the lower $32 \mathrm{~km}$ of the glacier from 2013 to 2016 (Fig. 9). We currently lack sufficient elevation data in the accumulation zone to determine the precise source of this mass. The constriction may still exert a control on the surge behavior of Donjek Glacier, but as the boundary between the lower 'surge-type' and upper 'normal' portions of the glacier.

Consistent with other findings (Ađalgeirsdóttir and others, 2005), our results suggest that surge-type glaciers can have a strong negative mass balance during a surge by moving large amounts of mass to lower, warmer elevations (Fig. 9). Immediately following a surge, the ablation area of a glacier can gain mass as it is dynamically refilled from an area above the reservoir zone. Thus, the mass loss during quiescence does not reflect the climatic mass balance of the glacier (cf. Gardelle and others, 2013). Instead, our results indicate that a climatic mass balance can be derived from surge-type glaciers by comparing the glacier surface elevation at equivalent points in a surge cycle (e.g. just before a surge event; Fig. 9). However, this study is limited in the spatial extent of elevation measurements by narrow lidar swaths collected in 2000, 2012 and 2016.

The relationship between mass balance and surging at Donjek may be complicated by the presence of the surgetype tributary glacier $23 \mathrm{~km}$ upstream of the terminus. Abe and others (2016) suggest that surges of this tributary occur independently of surges of the main trunk, but because the tributary adds mass to the trunk it could cause the trunk to surge sooner than it would do otherwise. Although the 1974 and 2010 tributary surges appear to have added mass to the trunk (Fig. 2b), it seems that they had little impact on the recurrence interval of the main glacier surges events. The surge-type tributary plays a minor role, if any, in the surging of Donjek Glacier.

\subsection{Surge mechanisms and comparison between events}

Robust observations of repeat surges in a glacier are rare due to decadal to multi-decadal surge recurrence intervals, the relatively short time period over which high resolution satellite observations exist and the scarcity of repeat elevation data. Variegated (Eisen and others, 2005), Lowell (Bevington and Copland, 2014), Bering (Fatland and Lingle, 1998; Burgess and others, 2012) and now Donjek Glaciers, are among the only glaciers to have both elevation and velocity measurements for multiple surge events. The surges of Variegated Glacier were all similar in timing and scope, except for the 1995 surge, which did not reach full maturity (Eisen and others, 2005). It is still difficult to assess variability in recent surges of Lowell Glacier due to a lack of elevation data and spatially extensive velocity maps (Bevington and Copland, 2014). The two recent surges of Bering Glacier have showed different initiation patterns and timing, as the 2008-2011 surge initiated over $90 \mathrm{~km}$ of Bering Glacier (Burgess and others, 2012) whereas the 1993-1995 surge had an isolated initiation zone (Fatland and Lingle, 1998; Burgess and others, 2012). 

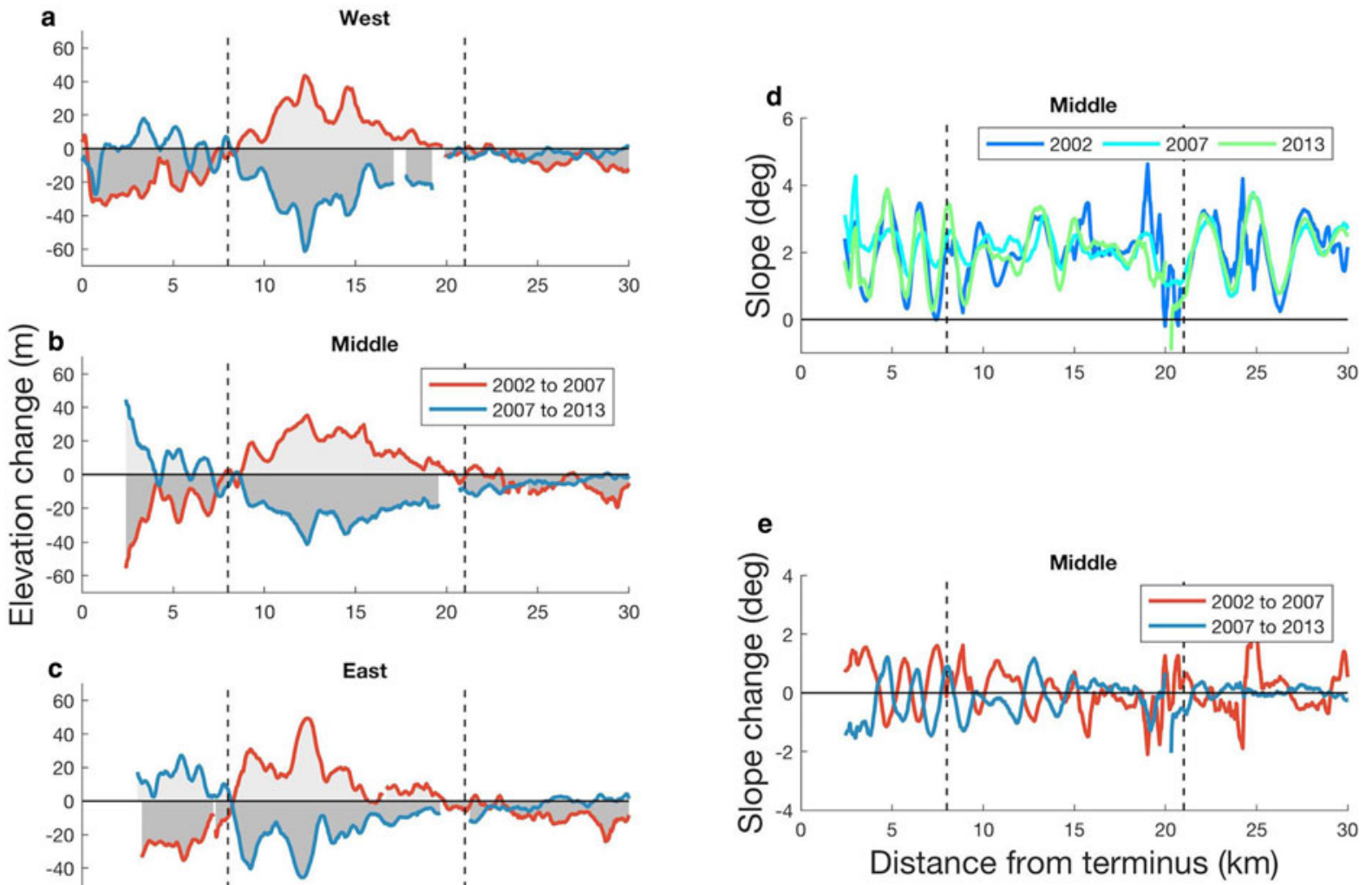

Fig. 7. The 2013 surge slope and elevation changes. (a-c) Elevation change for each flowline from 26 May 2002 to 13 September 2007 (red) and 22 May 2012 to August/September 2013 mosaic (blue). (d) Absolute slope of the middle profile for 26 May 2002 (dark blue), 13 September 2007 (medium blue) and the August/September 2013 mosaic (light blue). (e) Slope difference for middle flowline on 26 May 2000 to 13 September 2007 (red) and 22 May 2012 to the August/September 2013 mosaic (blue). Extent of the reservoir zone indicated by black dashed lines at 8 (dynamic balance line) and $21 \mathrm{~km}$ from the terminus. Note that elevation and slope changes have been smoothed with a $0.3 \mathrm{~km}$ moving window.

The surge time series presented here suggests that Donjek Glacier may have multiple surge initiation mechanisms. During some surge events the terminus begins to advance first, while the entire glacier starts moving at surge initiation in other events (Fig. 3). The 1977-1979 and 2012-2014 surge events both exhibited rapid motion of upstream ice (1-21 km from terminus) followed by terminus advance, while the 1988-1990 and 2000-2002 events exhibited terminus advance followed by upstream speedup (Fig. 3). Terminus advance appears to consistently occur at approximately the same time of year (August-September) for each surge event, regardless of velocity further up glacier (Fig. 3). We hypothesize that a surge can be trigged in two different ways, observed as up-glacier velocity increase or near-terminus advance, at Donjek Glacier, potentially related to how the subglacial drainage system is routed. We do not observe any kinematic waves propagating up or down glacier, suggesting that meltwater at the bed of the glacier acts over the lowest $21 \mathrm{~km}$ of the glacier nearly equally and/or rapidly propagates (in a matter of hours or days). However, the specific surge mechanisms at Donjek remain an open question that requires further research to address.

While we observe different patterns in surge initiation and termination, the location of the dynamic balance line appears to be controlled by the bed or valley curvature or both. We observe the dynamic balance line to be in the same location for the two most recent surge events with elevation measurements, for which we also observe the upper limit of surge activity to be at $\sim 21 \mathrm{~km}$ upstream of the terminus. The geology underlying Donjek Glacier is composed of Silurian limestone, marble, argillite and phyllite in the accumulation area to Pennsylvanian quartz monzodiorite and diorite, and Devonian quartz-rich, micaceous, calcareous siltstone to sandstone in the lowest $22 \mathrm{~km}$ (Yukon Geological Survey, 2018). The terminus of Donjek sits on a strike-slip fault running east-west (Yukon Geological Survey, 2018). The lithological transition suggests that bedrock geology may have a control on the segment of Donjek Glacier that exhibits surge-type behavior. However, it is unclear if the valley constriction or the transition in bedrock lithology determines the upper limit (Fig. 1). Observations of other glaciers suggest that geology can favor surge-type over 'normal' glaciers (Jiskoot and others, 2000, 2003), but there appears to be no spatial pattern among the geology underlying surge-type glaciers in the Yukon (Clarke and others, 1986; Crompton and others, 2018). Observations of the bed profile, glacier thickness and substrate (bedrock type; till properties; etc.) are needed to better understand the causes and spatial extent of surging on Donjek Glacier.

\subsection{Surge frequency and extent}

Long-term changes in mass balance can cause changes in glacier surge frequency within a region (Dowdeswell and 


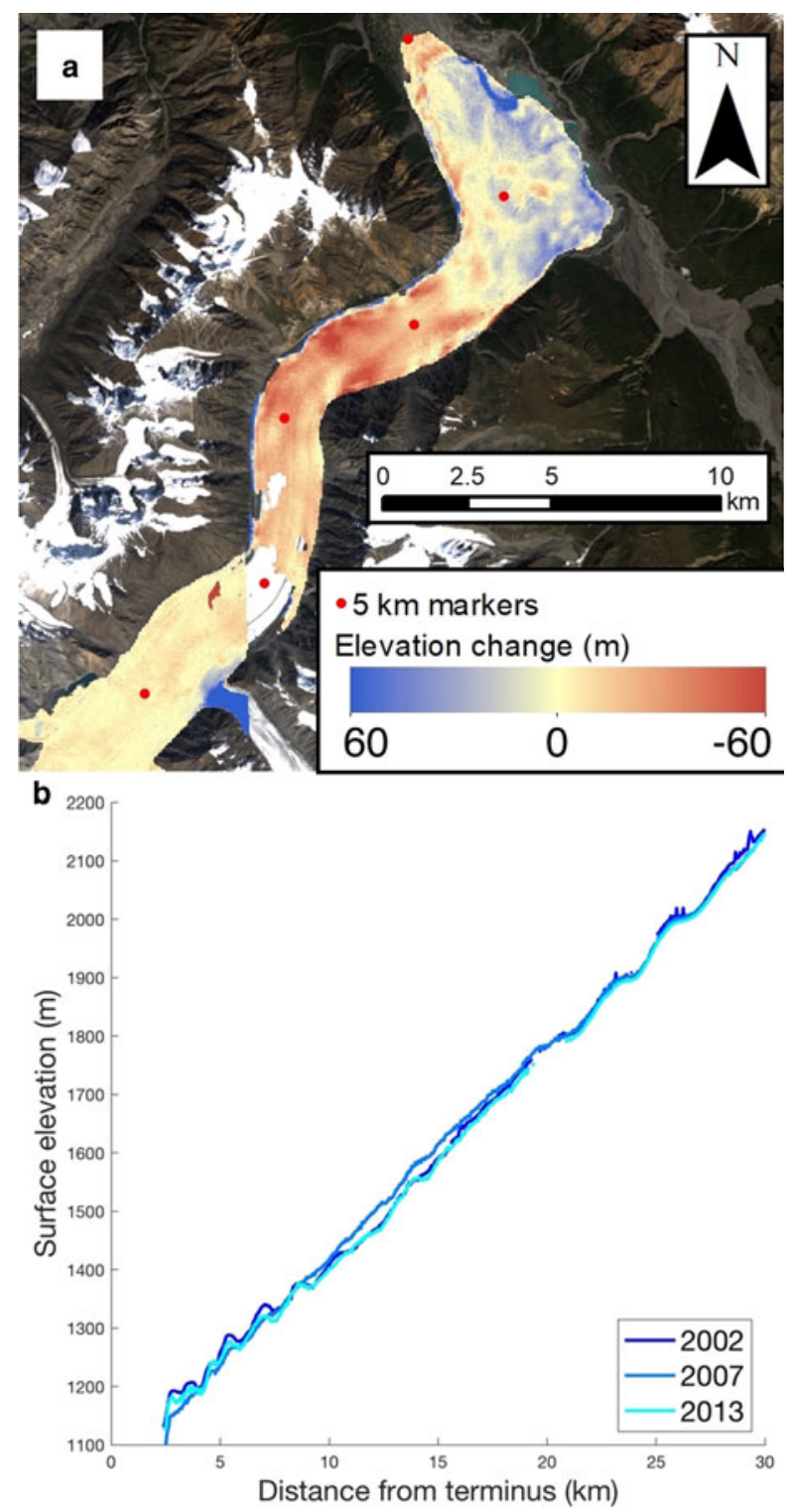

Fig. 8. Absolute elevation change. (a) Elevation change from 13 September 2007 to August/September 2013 mosaic from red (negative) to blue (positive). Image is Landsat 8 scene from 22 July 2014 at the end of the 2012-2014 surge events. (b) Absolute elevation for middle profile on 30 May 2000 (dark blue), 22 May 2012 (medium blue) and the August/September 2013 mosaic (light blue). Surge events occurred from 2000 to 2002 and 2012 to 2014.

others, 1995; Copland and others, 2011). Although Donjek Glacier has experienced a negative mass balance in recent decades (Larsen and others, 2015) the recurrence interval of 12 years since the 1988-1990 surge event has not changed. While the quiescent interval appears to be 2 years shorter from 1980 to 1988 than it has been since that time (Table 4), we are unable to confidently measure quiescent phase length in earlier time periods. Interestingly, despite the largely constant repeat interval, the most recent active phase from 2012 to 2014 was the shortest on record at 1.28-1.69 years (Table 4). Despite the improved characterization of surging presented here, there is still insufficient evidence to state whether the duration of the recurrence interval, the quiescent phase or the active phase is changing significantly through time. The long-term negative mass balance in the study region has likely caused each of the

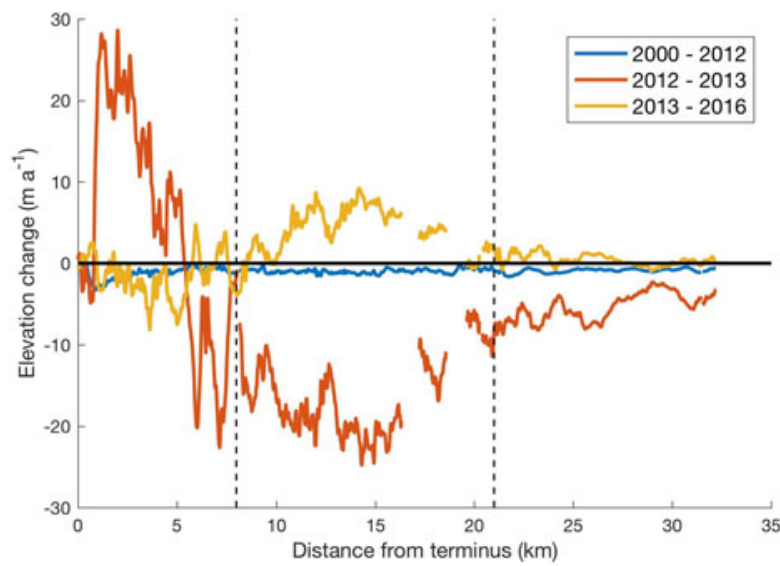

Fig. 9. Glacier surface elevation change from 2000 to 2016 . Glacier surface elevation change derived from IceBridge lidar (2000, 2012 and 2016) and WorldView (2013) elevation models. Lidar flight line is shown in Figure 1. We show change from 30 May 2000 to 22 May 2012 (blue) and change from 22 May 2012 to the August/ September 2013 mosaic (red). Elevation change from the August/ September 2013 mosaic to 15 May 2016 is shown in yellow. Extent of the reservoir zone indicated by black dashed lines at 8 $\mathrm{km}$ (dynamic balance line) and $21 \mathrm{~km}$ from the terminus. Note difference in profile location from Figures 6 and 7 due to 2000 flight line (Fig. 1).

successive surge events to be less extensive than the last (Fig. 2), consistent with the findings of Abe and others (2016). The next surge of Donjek Glacier is projected to occur in the mid-2020s, based on a consistent 12-year repeat interval, and will likely be less extensive than the 2014 maximum surge extent.

\subsection{Comparison to other surge-type glaciers}

Although other authors have found that glacier surges in Alaska tend to initiate in winter (Raymond, 1987; Harrison and Post, 2003; Abe and Furuya, 2014), we show that the 1977-1979, 1988-1990, 2000-2002 and 2012-2014 surges of Donjek Glacier initiated in summer, similar to West Fork Glacier, Alaska (Harrison and others, 1994). Furthermore, Abe and Furuya (2014) found that surge-type glaciers in their quiescent phase frequently have higher winter than summer velocities. However, at Donjek Glacier, inter-annual variability during quiescence is greater than the seasonal difference between summer (Abe and others, 2016) and winter velocity (Van Wychen and others, 2018).

Velocity cross sections show that sliding is likely the dominant mechanism of increased motion during the surge phase of Donjek Glacier as glacier velocity is elevated nearly uniformly across the width of the glacier (Fig. 5). This is consistent with the commonly observed 'plug flow' during surges (Kamb and others, 1985; Harrison and others, 1994; Murray and others, 2003; Pritchard and others, 2005). It is difficult to discern patterns in velocity across the width of glaciers in their surge phase due to a lack of observations.

Steele ( $\sim 35 \mathrm{~km}$ long), Lowell ( $65 \mathrm{~km}$ long) and Trapridge Glaciers $(<3 \mathrm{~km})$ are the three geographically closest surgetype glaciers to Donjek that have received considerable attention. The 1966-1968 surge of Steele Glacier caused the ice surface to uplift $260 \mathrm{~m}$ (Stanley, 1969). Altena and others (2019) found that Steele surged again between 2014 and 2016, although it has not yet been thoroughly documented. 
Table 5. Surge elevation change, zone length and glacier details from around the world

\begin{tabular}{|c|c|c|c|c|c|c|c|c|c|}
\hline Glacier name & Location & Surge year & $\begin{array}{l}\text { Maximum measured } \\
\text { elevation increase/ } \\
\text { decrease }(m)^{a}\end{array}$ & $\begin{array}{c}\text { Dynamic balance } \\
\text { line distance from } \\
\text { terminus }(\mathrm{km})^{\mathrm{b}}\end{array}$ & $\begin{array}{l}\text { Reservoir zone } \\
\text { length }(\mathrm{km})\end{array}$ & $\begin{array}{l}\text { Glacier } \\
\text { length }(\mathrm{km})\end{array}$ & $\begin{array}{l}\text { Snowline relative to } \\
\text { reservoir zone }\end{array}$ & $\begin{array}{l}\text { Years since previous } \\
\text { surge (years) }\end{array}$ & Source \\
\hline Muldrow & Alaska & 1956 to 1957 & $\sim+200 / \sim-100$ & 17 & 20 & $\sim 63$ & Up-glacier & $>50$ & Post (1960) \\
\hline West Fork & Alaska & 1987 to 1988 & $+120 /-70$ & 16 & 21 & $\sim 40$ & Within & 52 & Harrison and others (1994) \\
\hline Variegated & Alaska & 1995 & $+110 /-40$ & 4 & 16 & $\sim 20$ & Within & 12 & Eisen and others (2005) \\
\hline Bering & Alaska & 2008 to 2011 & $+20 /-110$ & $120-130$ & $>30$ & $\sim 165$ & Unknown & 13 & Burgess and others (2012) \\
\hline Sortebræ & Greenland & 1992 to 1995 & $+145 /-270$ & 16 & 46 & 65 & Up-glacier & $\sim 45$ & $\begin{array}{l}\text { Jiskoot and others (2001), } \\
\text { Pritchard and others (2003) }\end{array}$ \\
\hline Sabche & Nepal & $2012-$ & $+90 /-60$ & 1.5 & 4.5 & 6.5 & Unknown & 10 & Lovell and others (2018) \\
\hline Khurdopin & Pakistan & 2017 & $+160 /-80$ & 12 & 13 & $\sim 41$ & Up-glacier & 18 & Steiner and others (2018) \\
\hline Usherbreen & Svalbard & 1978 to 1985 & $+150 / \geq-70$ & 4.8 & $>2$ & 12 & Unknown & Unknown & Hagen (1987) \\
\hline Comfortlessbreen & Svalbard & 2006 to 2010 & $\sim 100 /-80$ to -100 & 9 & $>3$ & $\sim 15$ & Within & $>70$ & King and others (2015) \\
\hline Osbornebreen & Svalbard & 1986 to 1988 & $+100 />-100$ & Unknown & Unknown & 20 & Unknown & Unknown & Rolstad and others (1997) \\
\hline Zawadzkibreen & Svalbard & $2000 \mathrm{~s}$ & $+70 /-40$ & 9 & 8.5 & 17.5 & Within & $\sim 70$ & Sund and others (2014) \\
\hline Bivachny & Tajikistan & 2012 to 2015 & $+85 /-68$ & 14.5 & $\sim 22.5$ & $\sim 37$ & Within & 21 & Wendt and others (2017) \\
\hline Medvezhiy & Tajikistan & 1988 to 1989 & $\sim+100 / \sim-20$ & 3 & 5 & $\sim 15$ & Up-glacier & 15 & Osipova and Tsvetkov (1991) \\
\hline Lowell & Yukon & 2009 to 2010 & $+60 /$ Unknown & $>25$ & Unknown & $\sim 65$ & Unknown & 12 & Bevington and Copland (2014) \\
\hline Donjek & Yukon & 2012 to 2014 & $+74 /-66$ & 8 & 13 & 65 & Up-glacier & 12 & This study \\
\hline Steele & Yukon & 1966 to 1968 & $+260 /-160$ & 8 to 13 & $>7$ & $\sim 35$ & Unknown & Unknown & Stanley (1969) \\
\hline
\end{tabular}

a Elevation change is dependent on timing of available DEMs.

b Terminus position defined by each study author. 
Lowell Glacier has experienced five surges since 1948, with recurrence intervals of 12-20 years (Bevington and Copland, 2014). Over the course of the 2009-2010 surge, Bevington and Copland (2014) measured a $60 \mathrm{~m}$ maximum increase in elevation of the glacier surface. Trapridge Glacier underwent a slow surge from $\sim 1980$ to 2000 leading to little surface uplift, however, the glacier advanced $450 \mathrm{~m}$ (Frappé and Clarke, 2007). Of these four well documented surge-type glaciers in the Yukon, Donjek has the shortest recurrence interval and displaces the second least amount of mass during a surge event after Trapridge Glacier.

Other surge-type glaciers in the Alaska region with surface elevation change observations include Muldrow (Post, 1960), West Fork (Harrison and others, 1994), Variegated (Eisen and others, 2005) and Bering Glaciers (Burgess and others, 2012; Table 5). Of these, Donjek Glacier experiences the least amount of elevation change in either the reservoir or receiving zone and has the least extensive reservoir zone. This suggests a connection between reservoir zone size and surge volume. While a great deal of work has been conducted on Trapridge Glacier (Clarke and others, 1984; Clarke and Blake, 1991; Frappé and Clarke, 2007), little work has been conducted to understand mass transfer from the reservoir to receiving zones for surge-type glaciers in general.

With the exception of Bering Glacier (Burgess and others, 2012), the maximum elevation gain is always larger than the minimum elevation loss for all surge-type glaciers in Alaska and the Yukon. Peak elevation loss exceeds elevation gain at the tidewater glacier Sortebrae in Greenland (Jiskoot and others, 2001), while tidewater glacier surges in Svalbard have almost equal peak elevation increase/decrease (Table 5). Variegated Glacier is the only known Alaskan glacier whose surge involves the entire length of the glacier (Eisen and others, 2005). Variegated is also one of the only two glaciers in the Alaska region which has its annual snowline within the reservoir zone (West Fork Glacier being the other; Table 5). Although it is possible that other surge-type glaciers exhibit similar elevation change characteristics as those mentioned here, it is difficult to compare surge phase elevation change to other glaciers around the world due to a lack of glacier wide elevation data.

\section{CONCLUSIONS}

Donjek Glacier has retreated $\sim 2.5 \mathrm{~km}$ since its pre-1874 Little Ice Age maximum extent to its most recent advanced post-surge position in 2014. Despite this retreat, and an overall negative mass balance, Donjek has surged regularly, with eight events since 1935 ( 1935, 1947, late-1950s, 1969, 1977-1979, 1988-1990, 2000-2002, 2012-2013) and a repeat interval of 9-12 years. During each of the last three surges Donjek increased in area by $3-7 \mathrm{~km}^{2}(0.7-2 \%$ of total area) due to terminus advance. We found that the 2000-2002 and 2012-2014 surge events initiated in summer months, but did not reach their full active phase until the following spring (2001 and 2013, respectively). The surge is limited to the lower $21 \mathrm{~km}$ of Donjek Glacier as mass is redistributed from the reservoir zone $(8-21 \mathrm{~km}$ from the terminus) to the receiving zone $(0-8 \mathrm{~km}$ from the terminus). Ice velocity is fastest in the receiving zone, reaching speeds as high as $1700 \mathrm{~m} \mathrm{a}^{-1}$. While the location of the dynamic balance line remains constant between recent surge events, observations suggest different ways in which surges can initiate for unique surge events. The entire portion of the glacier affected by the surge begins to move rapidly before we observed terminus advance for the 1977-1979 and 2012-2014 surge events, while the opposite is true for the 1988-1990 and 2000-2002 events. This suggests that Donjek surge events can be triggered at different locations, and perhaps by different mechanisms.

Abe and others (2016) hypothesized that significant narrowing of the valley at $21 \mathrm{~km}$ from the terminus controlled the surging of Donjek Glacier, but we show here that the constriction actually defines the upper end of the active surge zone. This surge zone corresponds to the part of Donjek Glacier underlain by metasedimentary rock, and the constriction corresponds to the area were the underlying lithology changes from metasedimentary up-glacier to igneous down-glacier (Fig. 1). Thus, the role of the constriction in surging is complicated as it represents both a change in geometry and lithology.

We find elevated rates of mass loss during the surge phase, while comparatively little mass is lost during quiescence. During the 2012-2013 surge event, Donjek Glacier had a net ice volume loss of $\sim 0.51 \pm 0.0022 \mathrm{~km}^{3}$ in the lower 21 $\mathrm{km}$ of the glacier, the active surge zone. In the few years following a surge event we observe the ablation area to have a positive geodetic mass balance, suggesting rapid refilling from up-glacier regions. Thus, it is vital that surge-type glacier mass balance measurements are undertaken at the same time in the surge cycle (e.g. immediately before or after a surge event) for inclusion in glacier response to climate studies (cf. Yde and Paasche, 2010) and mass balance inventories (cf. Larsen and others, 2015).

\section{ACKNOWLEDGEMENTS}

WK is supported by the National Science Foundation Graduate Research Fellowship under Grant No. DGE1144205. WK thanks Dan and Betty Churchill for providing funding for a 2017 field season. LC thanks the Natural Sciences and Engineering Research Council of Canada, University of Ottawa and Polar Continental Shelf Program for funding and field logistics. KK thanks the NSF for funding St. Elias research, NSF AGS-1502783. WorldView DEMs were provided by the Polar Geospatial Center under NSFOPP awards 1043681, 1559691 and 1542736. We thank William Hauer at the Alaska Satellite Facility for his assistance tracking down Austin Post's air photographs, the Yukon Energy, Mines and Resources Library for scanning air photographs, and the University of Ottawa Geographical, Statistical and Government library for ordering air photographs. This work used the Extreme Science and Engineering Discovery Environment (XSEDE), which is supported by the National Science Foundation grant number ACl-1548562. This work used XSEDE Bridges GPU at the Pittsburg Super Computing Center through allocation DPP170002.

\section{REFERENCES}

Abe T and Furuya M (2014) Winter speed-up of quiescent surgetype glaciers in Yukon, Canada. Cryosphere, 9, 1183-1190 (doi: 10.5194/tc-9-1183-2015)

Abe T, Furuya M and Sakakibara D (2016) Brief communication: twelve-year cyclic surging episodes at Donjek Glacier in Yukon, Canada. Cryosphere, 10(4), 1427-1432 (doi: 10.5194/ tc-10-1427-2016)

Ađalgeirsdóttir $G$, Björnsson $H$, Pálsson $F$ and Magnússon $E$ (2005) Analyses of a surging outlet glacier of Vatnajökull ice 
cap, Iceland. Ann. Glaciol., 42, 23-28 (doi: 10.3189/ 172756405781812934)

Altena B, Scambos T, Fahnestock M and Kääb A (2019) Extracting recent short-term glacier velocity evolution over Southern Alaska from a large collection of Landsat data. Cryosph. Discuss., 13, 1-27 (doi: 10.5194/tc-13-795-2019)

Bevington A and Copland L (2014) Characteristics of the last five surges of Lowell Glacier, Yukon, Canada, since 1948. J. Glaciol., 60(219), 113-123 (doi: 10.3189/2014JoG13J134)

Björnsson H, Pálsson F, Sigurđsson O and Flowers GE (2003) Surges of glaciers in Iceland. Ann. Glaciol., 36, 82-90 (doi: 10.3189/ 172756403781816365)

Burgess EW, Forster RR, Larsen CF and Braun M (2012) Surge dynamics on Bering Glacier, Alaska, in 2008-2011. Cryosphere, 6(6), 1251-1262 (doi: 10.5194/tc-6-1251-2012)

Clarke G and Blake E (1991) Geometric and thermal evolution of a surge-type glacier in its quiescence state: Trapridge Glacier, Yukon Territory, Canada, 1969-89. J. Glaciol., 37(125), 158-169

Clarke GKC and Collins SG (1984) The 1981-1982 surge of Hazard Glacier, Yukon Territory. Can. J. Earth Sci., 21(3), 297-304 (doi: 10.1139/e84-032)

Clarke GKC and Holdsworth G (2002) Glaciers of the St. Elias mountains. In Williams R and Ferrigno J, eds. Satellite image atlas of the world. US Geological Survey, Washington, DC, Professional Paper 1386J, J301-J328

Clarke GKC and Mathews WH (1981) Estimates of the magnitude of glacier outburst floods from lake Donjek, Yukon-Territory, Canada. Can. J. Earth Sci., 18(9), 1452-1463

Clarke GKC, Collins SG and Thompson DE (1984) Flow, thermal structure, and subglacial conditions of a surge-type glacier. Can. J. Earth Sci., 21, 232-240 (doi: 10.1139/e84-024)

Clarke GKC, Schmok JP, Ommanney CSL and Collins SG (1986) Characteristics of surge-type glaciers. J. Geophys. Res. Solid Earth, 91(B7), 7165-7180

Copland L and 7 others (2011) Expanded and recently increased glacier surging in the Karakoram. Arct. Antarct. Alp. Res., 43 (4), 503-516 (doi: 10.1657/1938-4246-43.4.503)

Crompton JW and Flowers GE (2016) Correlations of suspended sediment size with bedrock lithology and glacier dynamics. Ann. Glaciol., 57(72), 142-150 (doi: 10.1017/aog.2016.6)

Crompton JW, Flowers GE and Stead D (2018) Bedrock fracture characteristics as a possible control on the distribution of surgetype glaciers. J. Geophys. Res. Earth Surf., 123(5), 853-873 (doi: 10.1002/2017JF004505)

Denton G and Stuiver M (1966) Neoglacial chronology, Northeastern St. Elias Mountains, Canada. Am. J. Sci., 264, 577-599

De Paoli L and Flowers GE (2009) Dynamics of a small surge-type glacier using one-dimensional geophysical inversion. J. Glaciol., 55(194), 1101-1112

Dolgoushin LD and Osipova GB (1975) Glacier surges and the problem of their forecasting. IAHS-AISH Publ., 104, 292-304

Dowdeswell JA and Benham TJ (2003) A surge of Perseibreen, Svalbard, examined using aerial photography and ASTER high resolution satellite imagery. Polar Res., 22(2), 373-383 (doi: 10.3402/polar.v22i2.6466)

Dowdeswell JA, Hodgkins R, Nuttall A-M, Hagen JO and Hamilton GS (1995) Mass balance change as a control on the frequency and occurrence of glacier surges in Svalbard, Norwegian High Arctic. Geophys. Res. Lett., 22(21), 2909-2912 (doi: 10.1029/95GL02821)

Dunse T and 5 others (2015) Glacier-surge mechanisms promoted by a hydro-thermodynamic feedback to summer melt. Cryosphere, 9, 197-215 (doi: 10.5194/tc-9-197-2015)

Eisen O, Harrison WD and Raymond CF (2001) The surges of variegated glacier, Alaska, U.S.A., and their connection to climate and mass balance. J. Glaciol., 47(158), 351-358 (doi: 10.3189/ 172756501781832179)

Eisen $\mathrm{O}$ and 5 others (2005) Variegated Glacier, Alaska, USA: a century of surges. J. Glaciol., 51(174), 399-406 (doi: 10.3189/ 172756505781829250)
Fatland DR and Lingle CS (1998) Analysis of the 1993-95 Bering Glacier (Alaska) surge using differential SAR interferometry. J. Glaciol., 44(148), 532-546 (doi: 10.3189/S0022143000002057)

Flink AE and 5 others (2015) The evolution of a submarine landform record following recent and multiple surges of Tunabreen glacier, Svalbard. Quat. Sci. Rev., 108, 37-50 (doi: 10.1016/j. quascirev.2014.11.006)

Flowers GE, Roux N, Pimentel S and Schoof CG (2011) Present dynamics and future prognosis of a slowly surging glacier. Cryosphere, 5, 299-313 (doi: 10.5194/tc-5-299-2011)

Frappé TP and Clarke GKC (2007) Slow surge of Trapridge Glacier, Yukon Territory, Canada. J. Geophys. Res. Earth Surf., 112(3), 117 (doi: 10.1029/2006JF000607)

Gardelle J, Berthier E, Arnaud Y and Kaab A (2013) Region-wide glacier mass balances over the Pamir-Karakoram-Himalaya during 1999-2011. Cryosphere, 7(6), 1885-1886

Girod L, Nuth C, Kääb A, McNabb R and Galland O (2017) MMASTER: improved ASTER DEMs for elevation change monitoring. Remote Sens., 9(7) (doi: 10.3390/rs9070704)

Hagen JO (1987) Glacier surge at Usherbreen, Svalbard. Polar Res. 5(2), 239-252 (doi: 10.1111/j.1751-8369.1987.tb00625.x)

Hamilton GS and Dowdeswell JA (1996) Controls on glacier surging in Svalbard. J. Glaciol., 42(140), 157-168 (doi: 10.1017/ S0022143000030616)

Harrison WD and Post A (2003) How much do we really know about glacier surging? Ann. Glaciol., 36(1), 1-6 (doi: 10.3189/ 172756403781816185)

Harrison WD, Echelmeyer KA, Chacho EF, Raymond CF and Benedict RJ (1994) The 1987-88 surge of West Fork Glacier, Susitna Basin, Alaska, USA. J. Glaciol., 40(135), 241-254 (doi: 10.1017/S0022143000007334)

Herreid S and Truffer M (2016) Automated detection of unstable glacier flow and a spectrum of speedup behavior in the Alaska range. J. Geophys. Res. Earth Surf., 121(1), 64-81 (doi: 10.1002/2015JF003502)

Howat IM, Smith BE, Joughin I and Scambos TA (2008) Rates of southeast Greenland ice volume loss from combined ICESat and ASTER observations. Geophys. Res. Lett., 35(17), L17505 (doi: 10.1029/2008GL034496)

Jarvis G and Clarke GKC (1975) The thermal regime of Trapridge Glacier and its relevance to glacier surging. J. Glaciol., 14(71), 235-250 (doi: 10.1017/S0022143000021729)

Jiskoot $\mathrm{H}$ and Juhlin DT (2009) Surge of a small East Greenland glacier, 2001-2007, suggests Svalbard-type surge mechanism. J. Glaciol., 55(191), 567-570

Jiskoot H, Murray T and Boyle P (2000) Controls on the distribution of surge-type glaciers in Svalbard. J. Glaciol., 46(154), 412-422

Jiskoot H, Pedersen AK and Murray T (2001) Multi-model photogrammetric analysis of the 1990s surge of Sortebræ, East Greenland. J. Glaciol., 47(159), 677-687

Jiskoot H, Murray T and Luckman A (2003) Surge potential and drainage-basin characteristics in East Greenland. Ann. Glaciol., 36, 142-148

Johnson PG (1972a) The morphological effects of surges of the Donjek Glacier, St Elias Mountains, Yukon Territory, Canada. J. Glaciol., 11(62), 227-234

Johnson PG (1972b) A possible advanced hypsithermal position of the Donjek Glacier. Arctic, 25(4), 302-305

Kamb B and 7 others (1985) Glacier surge mechanism: 1982-1983 surge of Variegated glacier, Alaska. Science, 227(4686), 469479 (doi: 10.1126/science.227.4686.469).

King O, Hambrey MJ, Irvine-Fynn TDL and Holt TO (2015) The structural, geometric and volumetric changes of a polythermal Arctic glacier during a surge cycle: Comfortlessbreen, Svalbard. Earth Surf. Process. Landforms, 41(2), 162-177 (doi: 10.1002/ esp.3796)

Korona J, Berthier E, Bernard M, Rémy F and Thouvenot E (2009) SPIRIT. SPOT 5 stereoscopic survey of polar ice: reference images and topographies during the fourth International Polar Year (2007-2009). ISPRS J. Photogramm. Remote Sens., 64, 204-212 
Kotlyakov VM and 8 others (2010) Glaciers of the former Soviet Union. In Williams RS, Jr. and Ferrigno JG eds. Satellite image atlas of glaciers of the world: glaciers of Asia. U.S. Geological Survey, Washington, DC, Professional Paper 1386-F, 1-58

Larsen CF and 5 others (2015) Surface melt dominates Alaska glacier mass balance. Geophys. Res. Lett., 42(14), 5902-5908 (doi: 10.1002/2015GL064349)

Lovell AM, Carr JR and Stokes CR (2018) Topographic controls on the surging behaviour of Sabche Glacier, Nepal (1967 to 2017). Remote Sens. Environ., 210(March), 434-443 (doi: 10.1016/j.rse.2018.03.036)

Luckman A, Murray T and Strozzi T (2002) Surface flow evolution throughout a glacier surge measured by satellite radar interferometry. Geophys. Res. Lett., 29(23), 10-1-10-4 (doi: 10.1029/ 2001GL014570)

Mansell D, Luckman A and Murray T (2012) Dynamics of tidewater surge-type glaciers in northwest Svalbard. J. Glaciol., 58(207), 110-118 (doi: 10.3189/2012JoG11J058)

Meier MF and Post A (1969) What are glacier surges? Can. J. Earth Sci., 6(4), 807-817 (doi: 10.1139/e69-081)

Murray T, Dowdeswell JA, Drewry DJ and Frearson I (1998) Geometric evolution and ice dynamics during a surge of Bakaninbreen, Svalbard. J. Glaciol., 44(147), 263-272 (doi: 10.1017/S0022143000002604)

Murray T, Strozzi T, Luckman A, Pritchard H and Jiskoot H (2002) Ice dynamics during a surge of Sortebræ, East Greenland. Ann. Glaciol., 34, 323-329 (doi: 10.3189/172756402781817491)

Murray T and 6 others (2000) Glacier surge propagation by thermal evolution at the bed. J. Geophys. Res. Solid Earth, 105(B6), 13491-13507 (doi: 10.1029/2000JB900066)

Murray T, Strozzi T, Luckman A, Jiskoot H and Christakos P (2003) Is there a single surge mechanism? Contrasts in dynamics between glacier surges in Svalbard and other regions. J. Geophys. Res. Solid Earth, 108(B5), 3-1-3-15 (doi: 10.1029/2002JB001906)

Noh M and Howat I (2015) Automated stereo-photogrammetric DEM generation at high latitudes: surface extraction from TIN-based search minimization (SETSM) validation and demonstration over glaciated regions. GISci. Remote Sens., 52(2), 198-217 (doi: 10.1080/15481603.2015.1008621)

Osipova GB and Tsvetkov DG (1991) Kinematics of the surface of a surging glacier (comparison of the Medvezhiy and Variegated Glaciers). IAHS Publ., 208, 345-357

Post A (1960) The exceptional advances of the muldrow, black rapids, and susitna glaciers. J. Geophys. Res., 65(11), 3703 (doi: 10.1029/JZ065i011p03703)

Post A (1969) Distribution of surging glaciers in Western North America. J. Glaciol., 8(53), 229-240 (doi: 10.1017/ S0022143000031221)

Pritchard H, Murray T, Strozzi T, Barr S and Luckman A (2003) Surgerelated topographic change of the glacier Sortebræ, East Greenland, derived from synthetic aperture radar interferometry. J. Glaciol., 49 (166), 381-390 (doi: 10.3189/172756503781830593)

Pritchard H, Murray T, Luckman A, Strozzi T and Barr S (2005) Glacier surge dynamics of Sortebræ, east Greenland, from synthetic aperture radar feature tracking. J. Geophys. Res. Earth Surf., 110(F3), F03005 (doi: 10.1029/2004JF000233)

Qiu J (2017) Ice on the run. Science, 358(6367), 1120-1123 (doi: 10.1126/science.358.6367.1120)

Quincey DJ, Glasser NF, Cook SJ and Luckman A (2015) Heterogeneity in Karakoram glacier surges. J. Geophys. Res. Earth Surf., 120(7), 1288-1300.

Raymond CF (1987) How do glaciers surge? A review. J. Geophys. Res., 92(1), 9121-9134
RGI Consortium (2017) Randolph glacier inventory - a dataset of global glacier outlines: version 6.0: technical report, global land ice measurements from space, Colorado, USA. Digit. Media (doi: 10.7265/N5-RGI-60)

Rolstad C, Amlien J, Hagen JO and Lundén B (1997) Visible and near-infrared digital images for determination of ice velocities and surface elevation during a surge on Osbornebreen, a tidewater glacier in Svalbard. Ann. Glaciol., 24, 255-261

Roush JJ, Lingle CS, Guritz RM and Fatland DR (2003) Surgefront propagation and velocities during the early-1993-95 surge of Bering Glacier, Alaska, U.S.A., from sequential SAR imagery. Ann. Glaciol., 36(8), 37-44 (doi: 10.3189/ 172756403781816266)

Schomacker A, Benediktsson ÍÖ and Ingólfsson Ó (2014) The Eyjabakkajökull glacial landsystem, Iceland: geomorphic impact of multiple surges. Geomorphology, 218, 98-107

Sevestre H and Benn DI (2015) Climatic and geometric controls on the global distribution of surge-type glaciers: implications for a unifying model of surging. J. Glaciol., 61(228), 646-662 (doi: 10.3189/2015JoG14J136)

Sevestre $\mathrm{H}$ and 6 others (2018) Tidewater glacier surges initiated at the terminus. J. Geophys. Res. Earth Surf., 123(5), 1035-1051 (doi: 10.1029/2017JF004358)

Shean DE and 6 others (2016) An automated, open-source pipeline for mass production of digital elevation models (DEMs) from very-high-resolution commercial stereo satellite imagery. ISPRS J. Photogramm. Remote Sens., 116, 101-117 (doi: 10.1016/j. isprsjprs.2016.03.012)

Stanley AD (1969) Observations of surge of steele Glacier, Yukon Territory, Canada. Can. J. Earth Sci., 6(4P2), 819-830 (doi: 10.1139/e69-082)

Steiner JF, Kraaijenbrink PDA, Jiduc SG and Immerzeel WW (2018) Brief communication: the Khurdopin glacier surge revisited extreme flow velocities and formation of a dammed lake in 2017. Cryosphere, 12(1), 95-101 (doi: 10.5194/tc-12-95-2018)

Sund M, Eiken T, Hagen JO and Kääb A (2009) Svalbard surge dynamics derived from geometric changes. Ann. Glaciol., 50 (52), 50-60 (doi: 10.3189/172756409789624265)

Sund M, Lauknes TR and Eiken T (2014) Surge dynamics in the Nathorstbreen glacier system, Svalbard. Cryosphere, 8(2), 623638 (doi: 10.5194/tc-8-623-2014)

Towns J and 12 others (2014) XSEDE: accelerating scientific discovery. Comput. Sci. Eng., 16(5), 62-74 (doi: 10.1109/ MCSE.2014.80)

Truffer M, Harrison WD and Echelmeyer KA (2000) Glacier motion dominated by processes deep in underlying till. J. Glaciol., 46 (153), 213-221 (doi: 10.3189/172756500781832909)

Van Wychen W and 5 others (2018) Surface velocities of glaciers in Western Canada from speckle-tracking of ALOS PALSAR and RADARSAT-2 data. Can. J. Remote Sens., 44(1), 57-66 (doi: 10.1080/07038992.2018.1433529)

Wendt A, Mayer C, Lambrecht A and Floricioiu D (2017) A glacier surge of Bivachny Glacier, Pamir Mountains, observed by a time series of high-resolution digital elevation models and glacier velocities. Remote Sens., 9(4), 388 (doi: 10.3390/ rs9040388)

Yde JC and Paasche O (2010) Reconstructing climate change: not all glaciers suitable. EOS (Washington, DC), 91(21), 189-191 (doi: 10.1029/2010EO210001)

Yukon Geological Survey (2018) Yukon digital bedrock geology. Yukon Geological Survey, Whitehorse, Yukon, Canada. http:// www.geology.gov.yk.ca/update_yukon_bedrock_geology_map. $\mathrm{html}$ 